\title{
Essay
}

\section{RATIONAL IGNORANCE AT THE PATENT OFFICE*}

\author{
Mark A. Lemley*
}

How much time and money should the Patent and Trademark Office spend deciding whether to issue a patent? To judge by recent criticism of the office from academics, industry leaders, and the press, the answer is "a lot more than it does now." The PTO has come under attack of late for failing to do a serious job of examining patents, thus allowing bad patents to slip through the system. ${ }^{1}$ The criticism is particularly strong in specific industries, notably software and Internet "business method" patents, in which the PTO has arguably failed to respond quickly enough to changing legal circumstances. ${ }^{2}$ Several solutions have been proposed,

\footnotetext{
* Yes, I know it's the Patent and Trademark Office, not the Patent Office. But nothing in this Essay applies to the PTO's trademark operations, and besides being awkward, using the full title might be misleading.

** Professor of Law, Boalt Hall School of Law, University of California at Berkeley; of counsel, Fish \& Richardson P.C.

The comments I received on early drafts of this paper were even more helpful than usual, and I have revised the paper quite substantially based on those comments. Thanks to John Allison, John Barton, Bob Cooter, Alison Derbenwick, Rochelle Dreyfuss, Aaron Edlin, Jesse Fried, Wendy Gordon, Rose Hagan, Justin Hughes, Mark Janis, Brian Kahin, Michael Katz, Jay Kesan, Dan Klerman, David McGowan, Peter Menell, Craig Nard, Cecil Quillen, Arti Rai, Pam Samuelson, Howard Shelanski, Deepak Somaya, Yossi Spiegel, Jay Thomas, Hans Troesch, Keith Witek and participants at the American Law and Economics Association meeting and the Olin Law and Economics Workshop at Boalt Hall for comments on an earlier draft, and to Frank Goldberg for outstanding research assistance.

${ }^{1}$ Complaints are legion. See, e.g., Julie E. Cohen, Reverse Engineering and the Rise of Electronic Vigilantism: Intellectual Property Implications of "Lock-Out" Programs, 68 S. CAL. L. REV. 1091, 1177-80 (1995); Andy Johnson-Laird, Looking Forward, Legislating Backward? 4 J. SMALL \& EMERging Bus. L. 95, 120-24 (2000); Jay P. Kesan \& Marc Banik, Patents as Incomplete Contracts: Aligning Incentives for R\&D Investment with Incentives to Disclose Prior Art, 2 WASH. U. J.L. \& POL'y 23 (2000); Robert P. Merges, As Many as Six Impossible Patents Before Breakfast: Property Rights for Business Concepts and Patent System Reform, 14 BERKELEY TECH. L.J. 577 (1999); John R. Thomas, Collusion and Collective Action in the Patent System: A Proposal for Patent Bounties (2000) (working paper, on file with author); Simson Garfinkel, Patently Absurd, WIRED, July 1994, at 104; James Gleick, Patently Absurd, N.Y. TimES MAGAZINE, Mar. 12, 2000, at 44; Lawrence Lessig, The Problem with Patents, STANDARD, Apr. 23, 1999, available at http://www.thestandard.com/article/display/ 0,1151,4296,00.html; Greg Ahronian, Patenting the Internet, Electronic Commerce, Bioinformatics, at http://www.bustpatents.com/index.html; Jeff Bezos, An Open Letter on the Subject of Patents, http://www.amazon.com/exec.obidos/subst/misc/patents.html.

2 This criticism has a great deal of force with respect to software patents, where the PTO clearly missed the ball for over a decade, failing to hire examiners skilled in the software arts or to allow software engineers to practice before it, and failing to classify software prior art well. See, e.g., Mark A. Lemley et AL., Software AND InTernet LaW 333-34 (2000); Cohen, supra note 1, at 1177-80; Julie E. Cohen \& Mark A. Lemley, Patent Scope and Innovation in the Software Industry, 89 CAL. L. REV. 1, $42-45$ (2001) (arguing that "significant defects in the PTO's ability to examine software patent applications remain unaddressed"). By contrast, the PTO has reacted much more quickly to the change in legal rules in 1998 that permitted the patenting of business methods. It developed new guidelines and started training examiners in 1999, and by 2000 had instituted special
} 
but the common thread among them seems intuitively obvious: the PTO should do a more careful job of reviewing patent applications and should weed out more "bad" patents.

Much of the criticism of the PTO is well-founded, and I have no intention of defending all of its policies ${ }^{3}$ or suggesting that all or even most of the patents it issues are worthwhile. ${ }^{4}$ But the situation is more complicated than this criticism suggests. Conducting a more thorough examination of patent applications requires society to spend more time and more money. Whether these increased resources would be spent wisely depends on the return we get for that money. It is that return on investment that I explore in a general way in this Essay. ${ }^{5}$

The essential insight of this Essay stems from the littleacknowledged fact that the overwhelming majority of patents are never litigated or even licensed. Because so few patents are ever asserted against a competitor, it is much cheaper for society to make detailed validity determinations in those few cases than to invest additional resources examining patents that will never be heard from again. In short, the PTO doesn't do a very detailed job of examining patents, but we probably don't want it to. It is "rationally ignorant" of the objective va-

review procedures for business method patents. See, e.g., John Schwartz, Online Patents to Face Tighter Review, WASH. POST, Mar. 30, 2000, at E1.

${ }^{3}$ For example, there are strong structural and psychological pressures on examiners to issue patents rather than reject applications, no matter how weak the alleged invention seems. Examiners have astonishingly little time to spend on each application - on average, a total of eighteen hours, including the time spent reading the application, reading the submitted prior art, searching for and reading prior art in databases accessible to the PTO, comparing that prior art to the application, writing an office action, reading and responding to the response to office action, iterating the last two steps at least one and often more times, conducting an interview with the applicant, and ensuring that the diagrams and claims are in form for allowance. Because so many applications arrive at the PTO each year, examiners are rewarded for getting applications out the door. See Merges, supra note 1, at 609 . And because of a bizarre set of prosecution rules, it is impossible to reject a patent once and for all. See 37 C.F.R. $\S \S 1.60(b)(4), 1.62$ (2000) (providing that after "final rejection," applicant can abandon and refile the same application - called a "continuation"- an unlimited number of times). Further, examiners must write up reasons for rejection, but not reasons for allowance, giving them more incentives to allow rather than reject an application. See, e.g., Thomas, supra note 1, at 21. Finally, the examiner has the burden of proof in rejecting a patent application. See, e.g., In re Oetiker, 977 F.2d 1443 (Fed. Cir. 1992); Thomas, supra note 1, at 21. Thus, the only way for an examiner to guarantee that an application is finally disposed of is to issue a patent. Examiners who want credit for dispositions therefore have a strong incentive to issue patents to persistent applicants, rather than to continue rejecting the applications. See Merges, supra note 1, at 590 (describing this process).

There are other, less tangible incentives for examiners to issue patents in doubtful cases. The PTO during the 1990s "reengineered" itself, declaring its mission to be "helping our customers get patents." This is an indefensible position for a quasi-judicial administrative agency that is trusted with representing the public interest in deciding whether to issue patents. While the job of the PTO is certainly to issue good patents, it is also to reject bad ones. The idea that applicants, rather than the public at large, are the intended beneficiaries of the patent system cannot help but contribute to the push to issue patents regardless of quality.

4 Recent evidence suggests that a large percentage - perhaps as many as half —of the patents that are eventually litigated to judgment are held invalid. See John R. Allison \& Mark A. Lemley, Empirical Evidence on the Validity of Litigated Patents, 26 AIPLA Q.J. 185 (1998).

5 While I have collected hard numbers for as many of the variables as possible, I wish to make clear that my goal is to work out some back-of-the-envelope numbers that can be used to set general policy. 
lidity of patents, in economics lingo, ${ }^{6}$ because it is too costly for the PTO to discover those facts.

In Part I, I set out the salient facts about patent prosecution and its costs. In Part II, I do the same with patent litigation and licensing, and explore what happens to the vast majority of patents that are never litigated or licensed. In Part III, I explore what these numbers mean for patent system reform. In Part IV, I respond to some likely objections to the argument I've presented. Finally, in Part V, I offer some policy proposals that stem from these ideas.

\section{The COST OF OBTAINING PATENTS}

The number of patents issued in the U.S. has been increasing. It gradually pushed past 100,000 per year during the 1980s and 1990s, and skyrocketed to about 150,000 per year beginning in 1998. In 2001, patents in force are those issued after the same date in 1984, with the exception of a small number that had "terminal disclaimers" reducing their terms, ${ }^{7}$ and a small number that had patent term extensions lengthening their terms. ${ }^{8}$

\begin{tabular}{|cc|}
\hline \multicolumn{2}{|c|}{ TABLE 1: UTILITY PATENTS IssuEd PER YEAR } \\
\hline Year of Issue & Number of Patents Issued \\
1999 & 153,493 \\
1998 & 147,521 \\
1997 & 111,983 \\
1996 & 109,646 \\
1995 & 101,419 \\
1994 & 101,676 \\
\hline
\end{tabular}

The data from the years before 1989 are substantially lower, but the estimated patents for the immediate future are even higher. PTO critic Greg Aharonian predicts the PTO will issue as many as 200,000 patents in $2000{ }^{10}$ The total number of patents in force as of this writing is approaching two million.

Not all patent applications result in issued patents. Historically, about sixty to sixty-five percent of patent applications have resulted in

\footnotetext{
6 The basic idea of rational ignorance is that any person will spend only a certain amount of time or money to obtain a piece of information. If obtaining that information costs more than the information is worth, they will (or should) rationally choose to remain ignorant of it. See RALPH T. BYRNS \& GERALD W. STONE, ECONOMICS 433 (4th ed. 1989) (discussing rational ignorance); Mancur Olson, Rational Ignorance, Professional Research, and Politicians' Dilemmas, in KNOWLEDGE, POWER AND THE CONGRESS 130 (William H. Robinson \& Clay H. Wellborn eds., 1991) (discussing the idea in the context of citizens and their rational ignorance of public policies).

7 See 37 C.F.R. $\S 1.321$ (addressing rules regarding terminal disclaimers).

8 See 35 U.S.C. $\S \S 155,155$ A, 156.

9 U.S. Patent and Trademark Office, U.S. Patent Statistics, Calendar Years 1963-2000 (2001), at http://www.uspto.gov/web/offices/ac/ido/oeip/taf/us_stat.pdf.

10 E-mail from Gregory Aharonian to Mark A. Lemley, Professor of Law, Boalt Hall School of Law, University of California at Berkeley (Sept. 15, 2000) (on file with author); see also Barrett J. Riordan, What's Driving Patent and Trade Mark Application Filings?, 2000 Eur. InTELL. Prop. REV. 349 ("[T] accelerating.").
} 
issued patents, according to PTO data. ${ }^{11}$ Table 2 shows the number of patent applications filed during the same period of years.

\begin{tabular}{||cc|}
\hline TABLE 2: UTILITY PATENT APPLICATIONS FILED PER YEAR & 12 \\
\hline Year of Application & Number of Applications Filed \\
1999 & 270,187 \\
1998 & 243,062 \\
1997 & 215,257 \\
1996 & 195,187 \\
1995 & 212,377 \\
1994 & 189,857 \\
\hline
\end{tabular}

Given the rate of increase, it is reasonable to project in future years a minimum of 275,000 applications and 150,000 issued patents per year.

Prosecuting patents is expensive. There is some disagreement on precisely how expensive it is, but the general range of costs for prosecuting a patent from start to finish (including application and various filing fees paid to the PTO, and attorney's fees not only to prepare and file the application, but to respond to office actions and continue prosecution through to issuance or abandonment) appears to be $\$ 10,000$ to $\$ 30,000$ per patent. ${ }^{13}$ I have chosen a conservative average estimate of $\$ 20,000$ per initial application taken through prosecution. Much of this cost is front-loaded: it covers an attorney's time in meeting with the inventor, writing the application, and writing patent claims, as well as a substantial filing fee to the PTO. Other costs are incurred on a piecemeal basis as prosecution progresses, and include both attorney's fees and PTO fees to file each new piece of paper, up to and including the issuance of the patent itself. These cost averages include both patents that are ultimately is-

11 See Cecil D. Quillen, Jr. \& Ogden H. Webster, Continuing Patent Applications and Performance of the U.S. Patent Office (2000) (working paper, on file with author). As Quillen and Webster point out in their astonishing paper, however, these numbers are misleading because they include a significant number of "continuation" applications and related refilings of previously-filed patent applications. I discuss their paper and its implications below.

12 U.S. Patent and Trademark Office, U.S. Patent Statistics, Calendar Years 1963-2000, supra note 9. Note that because the average patent application takes over two and a half years to mature into an issued patent, it is impossible to compare applications and issued patents year for year. See John R. Allison \& Mark A. Lemley, Who's Patenting What? An Empirical Exploration of Patent Prosecution, 53 VAND. L. REV. 2099, 2118 (2000). One can get a sense for the likely number of patents to issue in the next few years, however, by applying the $60-65 \%$ rule of thumb to the number of applications filed in the last few years.

13 There is a great deal of variance in estimates of these numbers, and very little hard statistical data. Part of the variance can be explained by the different degrees of complexity in different applications. Short applications with few claims that are allowed almost immediately obviously cost less than long applications with multiple claims that spend a great deal of time in prosecution. Some estimates follow: Erwin F. Berrier, Jr., Global Patent Costs Must Be Reduced, 36 IDEA 473, 476-77 (1996) (describing "cradle-to-grave" costs of prosecution as $\$ 14,370$ for a typical application); Jon D. Grossman \& Eric Oliver, A Step-by-Step Guide to Prosecuting Business Method Patents, 17:3 COMP. L., Mar. 2000, at 6, 9 ("[T] he median cost of preparing and prosecuting a utility patent application approaches \$15,000 in legal fees alone." (citing the 1997 American Intellectual Property Law Association (AIPLA) Economic Survey of Patent Lawyers)); Wayne M. Kennard, Obtaining and Litigating Software Patents, 430 PLI/PAT 193, 208 (1996) (estimating the average cost for preparing patent applications in the software field to be $\$ 10,000$ to $\$ 30,000$, and the average cost of prosecuting them to be another $\$ 10,000$ to $\$ 20,000)$.

Note that none of these estimates include either appeals or interferences, which obviously raise the cost a great deal. 
sued and patent applications that are ultimately rejected by the PTO without being revived.

A significant percentage of the total applications filed in the PTO, however, are not initial applications but continuing prosecution applications. ${ }^{14}$ Quillen and Webster collect data from the PTO showing that in the $1990 \mathrm{~s}, 28.4 \%$ of all applications filed were continuing prosecution applications. ${ }^{15}$ Continuing prosecution applications are much less expensive than initial applications, because in many cases the specification has already been written and much of the prior art has already been researched. I will use a conservative cost estimate of $\$ 5,000$ per continuation application.

With these numbers, we are in a position to calculate some approximate annual costs of patent prosecution. ${ }^{16}$ Of the 275,000 applications filed per year, $28.4 \%$, or 78,100 , are continuation applications. The cost of 196,900 regular applications prosecuted through to issuance or rejection at $\$ 20,000$ per patent totals $\$ 3.94$ billion. An additional 78,100 continuing patent applications at $\$ 5,000$ per patent costs $\$ 391$ million. This gives us a total annual cost of $\$ 4.33$ billion for domestic patent prosecution.

What does this money buy? The answer is, surprisingly little actual assessment of whether a patent should issue. The patent prosecution process is ex parte - the only participants are the applicant seeking a patent and the examiner, who is both judge and devil's advocate. ${ }^{17}$ While patent applicants must submit to the PTO relevant prior art of which they are aware, ${ }^{18}$ they are under no obligation to search for prior art, and most do not. The examiner, then, has the burden of reading the application, searching for and identifying the relevant prior art, reading the relevant prior art, deciding whether the application should be allowed by comparing the claims to the prior art, and writing an "Office Action" explaining the reasons why any claims are rejected. After the applicant writes a response to the examiner's evaluation, this process will normally happen again, and may happen several more times. The examiner may also conduct an "interview" with the applicant to discuss allowance in person or over the phone. Finally, there are technical matters that the examiner must identify and attend to before the patent application is in condition for allowance. The total average time the examiner spends on all these tasks over the two- to three-year prosecution of the patent is eighteen

\footnotetext{
${ }^{14}$ By the use of this term here, I mean to include divisionals, continuations, and continuation-inpart applications.

${ }^{15}$ See Quillen \& Webster, supra note 11.

${ }^{16}$ I should emphasize that these are costs in the United States alone. Patent applicants that want protection outside the United States must pay radically more, as they must replicate the prosecution process in many different countries.

17 The patent law was recently amended to provide for third-party participation in the reexamination of patents that the PTO has already issued. See 35 U.S.C. $\S \S 311-318$ (West Supp. 2000). However, virtually no one is expected to use this system, because doing so precludes you from challenging the validity of a patent in later litigation. $§ 315(\mathrm{c})$; see Mark D. Janis, Inter Partes Patent Reexamination, 10 Fordham InTELL. Prop. Media \& ENT. L.J. 481, 493 (2000) (arguing that Congress "has exacted a very high price for participation in an inter partes reexamination").

1837 C.F.R. $\S 1.56$.
} 
hours. ${ }^{19}$ It is not surprising, therefore, that the PTO issues many patents that would have been rejected had the examiner possessed perfect knowledge. This is particularly true since much of the most relevant prior art isn't easy to find-it consists of sales or uses by third parties that don't show up in any searchable database and will not be found by examiners in a hurry. Indeed, in litigated cases that actually result in a final judgment on validity, issued patents are held invalid forty-six percent of the time. ${ }^{20}$

\section{What PATENTEes Do WITH Their PATENTS}

To evaluate whether additional time and money investigating patent applications would be well spent, we also need an idea of what patentees actually do with their patents. Surprisingly, hard data on this question are hard to come by. The traditional incentive story relied upon by intellectual property scholars assumes that people seek patents to obtain exclusive rights to a technology, and that they use those patents either to exclude competitors from the market or to obtain licensing revenue in exchange for permitting the use of the patented technology. ${ }^{21}$ This story is not only incomplete, but dramatically so. ${ }^{22}$ The limited data we have suggest that the overwhelming majority of patents are neither litigated nor licensed.

\section{A. Litigation}

Of the roughly two million patents currently in force, ${ }^{23}$ only a tiny number are the basis for lawsuits each year. About 1,600 patent lawsuits are filed each year, ${ }^{24}$ involving at most perhaps 2,000 different patents. ${ }^{25}$

19 See, e.g., Brenda Sandburg, Speed Over Substance?, InTELl. Prop. MAG., Mar. 1999 (estimating eighteen hours on average; examiners may spend more time on complex technologies); Thomas, supra note 1, at 10 (estimating sixteen to seventeen hours); Interview with Q. Todd Dickinson, Director of the U.S. PTO, in Berkeley, Cal. (Apr. 2000); cf. Patent Nonsense: The Knowledge Monopolies, ECONOMIST, Apr. 8, 2000 ("[P]atent examiners spend only eight hours on a patent, on average.").

I should make it clear that this is an average across all industries, and that there may be substantial variation in the hours spent from one industry to another. See Interview with Q. Todd Dickinson, supra (stating that the hours spent range from eight per patent in some art units to thirty-two in other art units).

${ }^{20}$ Allison \& Lemley, supra note 4, at 205-06.

21 See, e.g., Mark A. Lemley, The Economics of Improvement in Intellectual Property Law, 75 TEX. L. REV. 989 (1997) (recounting the traditional story and citing sources).

22 See Mark A. Lemley, Reconceiving Patents in the Age of Venture Capital, 4 J. SMALL \& EMERGING Bus. L. 137 (2000) (questioning the traditional incentive story and seeing a need for research into the real causes of innovation).

${ }^{23}$ See supra notes 7-12 and accompanying text.

24 The exact data for the years 1995-1999 can be found in the Derwent Litalert database, available at http://www.derwent.com/intellectualproperty/litalert.html. The data that follow were compiled as of June 1, 2000, and involve cases labeled "patent."

$\begin{array}{cc}\text { Year } & \text { Number of Cases Filed } \\ 1999 & 1,652 \\ 1998 & 1,730 \\ 1997 & 1,731 \\ 1996 & 1,514 \\ 1995 & 1,258\end{array}$

Strictly speaking, I should consider the number of cases likely to be filed 5-6 years into the future, 
The overwhelming majority of these lawsuits settle or are abandoned before trial. Only about one hundred cases per year (and 125 patents) actually make it to trial. ${ }^{26}$ Based on these numbers, it is reasonable to estimate that at most only about two percent of all patents are ever litigated, and less than two-tenths of one percent of all issued patents actually go to court. ${ }^{27}$

When patent litigation does occur, it is expensive. The American Intellectual Property Law Association reports, based on a survey of its members, that the median cost of patent litigation to each side is $\$ 799,000$ through the end of discovery, and $\$ 1,503,000$ through trial and appeal. ${ }^{28}$ Estimating a total annual cost requires us to compute the cost of cases that go to trial $(\$ 1,503,000 \times 100$ cases $\times 2$ parties $=\$ 301$ million) and the cost of cases that are filed but settle before trial. ${ }^{29}$ In the latter case, multiplying $\$ 799,000$ times the 1,500 cases annually filed but not taken to trial times two parties gives us a cost estimate of $\$ 2.4$ billion. In practice, however, some cases will settle early and therefore not incur this $\cos ^{30}$ (though based on my anecdotal experience, cases are more likely to settle late in the litigation process, when the cost and uncertainty of trial is looming). To account for this, let us assume that the cost of cases settled before trial is only three-fourths of $\$ 2.4$ billion, or $\$ 1.8$ billion. This $\$ 1.8$ billion plus $\$ 301$ million gives us a total annual amount spent on patent litigation of $\$ 2.1$ billion. ${ }^{31}$ It is worth noting that

since patent lawsuits aren't normally filed immediately after the patent issues. $C f$. Allison \& Lemley, supra note 4, at 236 Table 12. The trends suggest that more cases will be filed in the future.

${ }^{25}$ Some patent lawsuits involve more than one patent. Two recent studies found about 1.25 patents were involved per lawsuit. See, e.g., Allison \& Lemley, supra note 4, at 205 (presenting data that show 299 patents in 239 cases actually resolved by opinion between 1989 and 1996, or 1.25 patents per cases); Kimberly Moore, Judges, Juries and Patent Cases-Empirical Evidence to Peek Inside the Black Box, 99 Mich. L. REV. 365 (2000) (providing data for all cases that went to trial between 1983 and 1999 that show 1733 patents in 1355 cases, or 1.28 patents per case). If about 1,600 different cases are filed per year, these data suggest that those cases would involve approximately 2,000 patents, unless there is some reason to believe cases that actually get resolved are likely to involve systematically more (or fewer) patents than those cases that settle. But some patents are doubtless included in more than one case, so the actual number of different patents litigated from each cohort should be somewhat less than 2,000.

${ }^{26}$ See Moore, supra note 25, at 24 (stating that the number of trials per year from 1988 to 1998 ranged from a low of 86 to a high of 108).

${ }^{27}$ If anything, these numbers are on the high side, because many patents that do go to court are litigated in more than one case. Thus, the total number of different patents litigated may actually be somewhat smaller.

Interestingly, the numbers appear to vary somewhat by industry. See Josh Lerner, Patenting in the Shadow of Competitors, 38 J. L. \& ECON. 463 (1995) (study showing that 6\% of biotechnology patents were involved in litigation).

28 AIPLA Report of Economic Survey (of U.S. IP Practitioners) (1999), cited in Craig P. Opperman, Computer Technology Patents (with an Emphasis on Internet \& E-Commerce Related Patents), 590 PLI/PAT 1039, 1047 (2000). The average cost of patent litigation is likely higher, because some extremely expensive cases will raise the average above the median. The study does report that the seventy-fifth percentile of patent cases cost $\$ 1,503,000$ to take through discovery, and $\$ 2,510,000$ through the end of the case.

29 This is only an estimate, because I have access only to the median cost and not the cost distribution. It is likely that these numbers therefore understate the costs of patent litigation somewhat, because extremely expensive cases aren't fully accounted for by the median number.

${ }^{30}$ Recall that the $\$ 799,000$ number represents a median only for cases that continue through the end of the discovery period, not for all cases settled short of trial.

31 An earlier and smaller estimate comes from Josh Lerner, who studied cases filed in 1991 and 
this number is only the cost of legal fees, and does not include the cost of judgments paid, which would raise defendant's costs but lower plaintiff's correspondingly. It also does not include indirect social costs such as judicial resources or the value of the time lost by corporate employees involved in the case.

Not all of this cost, of course, is attributable to litigating the validity or enforceability of the patent. Virtually every patent infringement lawsuit includes a claim that the patent is either invalid or unenforceable due to inequitable conduct (or commonly both). But these cases also involve infringement allegations that must be litigated, and commonly include ancillary issues as well (e.g., damages and license questions). Validity requires a great deal of attention, however. In contrast to the eighteen hours an examiner will spend on a patent from start to finish, lawyers and technical experts will spend hundreds and perhaps even thousands of hours searching for and reading prior art, poring over the specification and prosecution history, and preparing and defending invalidity arguments. A rough estimate may be that half of the cost of patent litigation - $\$ 1.05$ billion per year - is attributable to disputes over the validity or enforceability due to inequitable conduct of the patents in suit. ${ }^{32}$ This leaves the remaining cost for infringement, license, antitrust, damages, willfulness and the related non-patent issues that are often litigated in patent cases.

\section{B. Unlitigated Patents}

What happens to the rest of the patents? A surprisingly large number of issued patents lapse for failure to pay required maintenance fees. ${ }^{33}$ Payment of these fees, which are relatively low, ${ }^{34}$ is a prerequisite to bringing a patent lawsuit: failure to pay maintenance fees is effectively an abandonment of the patent. ${ }^{35}$ The evidence presented in Table 3 suggests that nearly two-thirds of all issued patents lapse for failure to pay maintenance fees before the end of their term: nearly half of all patents are abandoned in this way before their term is half over. Most of these patents aren't litigated or licensed during the short time they are in force. $^{36}$

determined that they would cost about $\$ 1$ billion. See Josh Lerner, Patenting in the Shadow of Competitors, 38 J.L. \& ECON. 463, 470 (1995).

32 It is possible that the amount of money litigants spend in lawsuits relates more to the perceived importance of the case and the litigant's financial condition than to the issues. Thus, if we were to remove validity issues entirely from litigation, it may be that the parties would simply spend more money litigating the other issues.

${ }^{33}$ Maintenance fees are due in increasing amounts at periods three and a half years, seven and a half years, and eleven and a half years after the patent issues. 35 U.S.C. § 41(b) (West Supp. 2000). For a pioneering study of maintenance fees and patent value, see Jean O. Lanjouw et al., How to Count Patents and Value Intellectual Property, 46 J. INDUs. ECON. 405 (1998).

34 The fees are $\$ 830$ at three and a half years, $\$ 1,900$ at seven and a half years, and $\$ 2,910$ at eleven and a half years. 35 U.S.C. $\$ 41(\mathrm{~b})$

35 The issue is more complicated, because it is sometimes possible to reinstate patents that have lapsed for failure to pay maintenance fees. See, e.g., Centigram Comm. Corp. v. Lehman, 862 F. Supp. 113 (E.D. Va. 1994)

36 Some patents that lapse may nonetheless have been used, and may merely have become irrelevant with the passage of time. But patents that are litigated or licensed are generally not those that expire for failure to pay the fairly modest maintenance fees. 
Obviously, though, many patents that do remain in force never get litigated. Some of these patents are licensed for royalties without litigation. Surprisingly, it does not appear that anyone knows precisely how many patents are licensed for royalties. ${ }^{37}$ There are reasons to believe, however, that the number is not large.

\begin{tabular}{||cc||}
\hline TABLE 3: PERCENTAGE OF PATENTS FOR WHICH \\
MAINTENANCE FEES WERE PAID \\
\hline Age of Patent $^{39}$ & Percentage Paid $^{38}$ P-1 year \\
$1-2$ & $100 \%$ \\
$2-3$ & $100 \%$ \\
$3-4$ & $100 \%$ \\
$4-5$ & $100 \%$ \\
$5-6$ & $82.56 \%$ \\
$6-7$ & $81.68 \%$ \\
$7-8$ & $80.77 \%$ \\
$8-9$ & $78.78 \%$ \\
$9-10$ & $57.43 \%$ \\
$10-11$ & $56.53 \%$ \\
$11-12$ & $56.14 \%$ \\
$12-13$ & $56.23 \%$ \\
$13-14$ & $37.05 \%$ \\
$14-15$ & $36.78 \%$ \\
$15-16$ & $36.00 \%$ \\
$16-17$ & $35.73 \%$ \\
\hline
\end{tabular}

First, many patentees engage in "defensive patenting," obtaining patents to stake their claim to an area of technology in hopes of preventing other companies from suing them. Indeed, there is anecdotal evidence that at least among high-technology and start-up companies, the primary purpose of patents is defensive. ${ }^{40}$ Licensing patents for royalties is correspondingly uncommon in many industries in which all the major

37 Jim Pooley has proposed that all license agreements be recorded in the PTO. James H.A. Pooley, The Trouble with Patents, CAL. LAW. (2000); cf. Ronald H. Coase, in EsSAYS ON ECONOMICS AND ECONOMISTS (1975) (proposing a national contracts database). In addition to being a good idea for the reasons he suggests, this proposal would have the collateral benefit of improving our knowledge about the patent system dramatically. In the absence of such a rule, this is an area that is ripe for research.

38 See E-mail from Paul Harrison, USPTO, to Franklin Goldberg, research assistant to Mark Lemley (June 6, 2000) (on file with author); see also Lanjouw et al., supra note 33, at 405. Data made available from Bill Brown, USPTO Maintenance Fee Office. The data are from 1998.

39 Maintenance fees are due at 3 and a half years, 7 and a half years, and 11 and a half years after the patent issues. See 35 U.S.C. $\$ 41($ b). Thus, for the first three years no fees are due, and the percentage is $100 \%$.

40 See, e.g., John H. Barton, Reforming the Patent System, 287 SCIENCE 1933 (2000) (arguing that reducing the number of patents would "help to solve the problem of defensive patent portfolios"); Lemley, Reconceiving Patents, supra note 22, at 143 ("One of the major reasons that companies get patents is that they're afraid that their competitors have them, and they don't want to be the only one left who doesn't have the ability to play in this game."); Scott Herhold, Patents Emerge as Online Battleground, S.J. MERCURY-NEWS, July 17, 1999 (quoting a venture capitalist as saying "None of my companies seek patent protection because they actually think it will protect them from competition. . . . Rather, they seek patents to protect themselves from other people who have patents."). 
players have large patent portfolios. Patent licensing in such an industry has a very different character from the typical model of licensing for royalties. Large companies tend to come to the table with hundreds of patents on each side, relying on volume rather than quality in a sort of "patent arms race." ${ }^{41}$ While some cross-licensing deals in such industries are royalty-bearing, it is more common for companies to agree to royalty-free cross-licenses, in which each party gets the freedom to make products but does not have to pay the other. Similarly, in many hightechnology industries patent rights are waived (or licensed on a royaltyfree basis, which amounts to the same thing) because the patented technology is adopted as an industry standard. ${ }^{42}$

Second, patentees who want to license their patents for royalties are typically parties with asymmetric stakes - they are individuals who don't sell products, "licensing shops" whose primary output is patents, or older companies that are no longer major players in the marketplace. Parties in these situations have no need to "trade" patents in the patent arms race described above. ${ }^{43}$ These patentees often approach an entire industry at once in an effort to maximize revenue. While some of those patents may be successfully licensed without litigation, it is more likely that at least one company they approach will opt to fight rather than take a license. If even one company does so, the patent is included in the litigation percentages cited above. ${ }^{44}$ Further, litigation may be a useful settlement strategy, forcing the other side to the bargaining table. Indeed, that appears to be what litigation normally is, since the overwhelming majority of patent lawsuits settle, presumably with some form of licensing deal.

Third, many companies obtain patents for reasons totally unrelated to litigation or licensing. Companies may patent broadly to "hedge their bets" if they are uncertain what patents are likely to have value ex post. Other companies, especially start-ups, obtain patents as a financing tool. ${ }^{45}$ Venture capitalists use client patents (or more likely, patent applications) as evidence that the company is well managed, is at a certain

41 See, e.g., Barton, supra note 40, at 1933 (suggesting that this practice is common in other industries as well); Bronwyn Hall \& Rosemarie Ham Ziedonis, The Patent Paradox Revisited: Determinants of Patenting in the U.S. Semiconductor Industry, NBER Working Paper 7062 (1999) (discussing such cross-license patterns in the semiconductor industry).

At a conference in November 2000, the former general counsel of a major semiconductor company said that at his company, intellectual property lawyers would index their patents against competitors' products, but wouldn't assert those patents in negotiations unless and until the competitor approached them first. My sense is that this anecdotal evidence is quite representative of the approach in many industries.

42 See Mark A. Lemley, Antitrust, Intellectual Property Rights and Standard-Setting Organizations (2001) (working paper, on file with author) (discussing organization rules that require licensing of intellectual property on favorable or even royalty-free terms).

43 Thus, Jerome Lemelson is famous for having licensed his patents aggressively, and Texas Instruments is the most aggressive licensor of patent in the semiconductor industry. Lemelson did not make any products himself, and therefore didn't need cross-licenses from anyone. Texas Instruments, while still a player in many markets, litigated primarily in the area of large-scale integrated circuits, in which it did not have significant sales by the time of the lawsuits.

44 Thus, both Lemelson and Texas Instruments licensed their patents without litigation on many occasions, but both have also been involved in multiple lawsuits over those patents.

45 See generally Charlotte H. Copperthite \& Michael J. Lerner, Creative Use of IP Portfolios Helps Secure Financing, NAT'L L.J., May 24, 1999 (discussing the role of IP rights in biotechnology financing). 
stage in development, and has defined and carved out a market niche. ${ }^{46}$ Established companies may patent out of inertia, to maintain a reputation as a market leader, or simply for the marquee value of selling a product with "patented technology." 77 Individuals employed by those companies may pursue a patent for its resume value, for the cash rewards that many companies pay, or simply because it is a routine and established policy. ${ }^{48}$ Finally, some patents are issued, especially to individuals, not because they have any market value but simply because the applicant really wants a patent on his invention, no matter how little commercial value it is likely to have. ${ }^{49}$

Even if a patent is obtained with an eye towards litigation or licensing, it may not be used in that way. Some patents get lost in a corporate bureaucracy - by the time the patent issues, it may be largely forgotten by the licensing or litigation departments of a large corporation, or ignored by the general counsel of a smaller company with other things on her mind. ${ }^{50}$ Other patents, even if filed with an intent to license or sue, may simply turn out not to be useful, either because the claims are too narrow or because by the time the patent issues the industry has moved in an unanticipated direction. There is certainly a strong sense in the patent community that many issued patents, even potentially valuable ones, sit around collecting dust. ${ }^{51}$

In terms of numbers, there is further work to be done. It is surprising that we don't have a very good idea of how many patents are actually licensed for revenue. My sense, however, is that a relatively small percentage of the 150,000 or so patents issued each year are actually li-

46 Lemley, Reconceiving Patents, supra note 22, at 143-44; cf. Samuel Kortum \& Josh Lerner, Does Venture Capital Spur Innovation? (1998) (NBER working paper W6846, on file with author) (finding that venture capital funding positively correlated with patenting).

47 See Ann Bartow, Separating Marketing Innovation from Actual Invention: A Proposal for a New, Improved, Lighter, and Better-Tasting Form of Patent Protection, 4 J. SMALL \& EMERGING BUS. L. 1 (2000) (describing the widespread use of patents for such purposes and identifying examples).

48 At a conference in November 2000, the chief patent counsel for a biotechnology company suggested that the demand in many technology-driven corporations for "metrics" to measure employees and departments drove individuals and groups within those companies to set numerical quotas for patents they would acquire.

49 Indeed, there is an entire book devoted to "oddball" patents on things like ear-flattening devices and thumb-wrestling rings that are unlikely ever to be licensed for royalties. See RICK Feinberg, Peculiar Patents (1994).

50 Sam Oddi reports old data that many patents did not cover products in use at all:

In an industry survey conducted in the early 1950s, it was concluded that: "The overall utilization rate of patents in current use, used in the past, and reported about to be used is 57 to $58 \%$."

The survey consisted of over 1,000 questionnaires returned by companies concerning their use

of patents. The study further concluded that the patent utilization rate is significantly higher

for smaller companies (over 75\%) compared to larger companies (close to $50 \%$ ).

A. Samuel Oddi, An Uneasier Case for Copyright Than for Patent Protection of Computer Programs, 72 NEB. L. REv. 351, 426 n.310 (1993) (citations omitted) (quoting Barkev S. Sanders et al., Patent Acquisition by Corporations, 3 PAT. TRAdemark \& Copyright J. Res. \& Educ. 217, 239 (1959)). See also British Technology Group, IPR Market Benchmark Study, http://www.btgplc.com (1998) (a survey of companies shows that only $15 \%$ had no unused patents in their portfolio, while $24 \%$ said they had over 100 unused patents, and $12 \%$ had more than 1,000 unused patents).

51 Thus, Kline and Rivette call their book on patents Rembrandts in the Attic because even those who are holding onto a valuable asset often don't know it. KEVIN G. RivetTE \& DAVID KLINE, REMBRANDTS IN THE ATTIC (2000). 
censed to third parties in exchange for royalties. As we have seen, only about $1.5 \%$ of all patents are litigated at all. The total number of patents licensed for royalties without even a complaint being filed is likely somewhat higher, but I suspect the total number of patents litigated or licensed for a royalty (as opposed to a cross-license) is on the order of five percent of issued patents.

The cost of licensing without going to court is also dramatically lower than the cost of litigation. Hard data are again difficult to find, but a reasonable estimate of the cost of negotiating a license might be $\$ 50,000$ per licensee per patent. ${ }^{53}$ Again, not all of this amount will be attributable to validity issues - the parties will also debate whether the patent covers the accused product, and what the appropriate royalty rate will be. Let us assume the validity investigation (normally requiring the accused infringer to obtain a written opinion of counsel) and debate in an average royalty-bearing patent license costs half of the total, or $\$ 25,000$. We then need to know how many licensees pay this cost for any given patent. Some patents are licensed only to one party; others may be licensed to a host of companies. But the more companies a patentee approaches, the more likely the patent will end up in at least one lawsuit. Further, patents asserted against a whole industry are likely to provoke concerted responses. Accused infringers may turn to a law firm or search firm that has already written opinions on this patent, reducing the cost of a validity evaluation. To account for these facts, I have assumed that the actual licensing cost to the industry is twice the cost of an individual license: $\$ 100,000$ total, with $\$ 50,000$ spent on validity. This gives us a total annual licensing cost outside of litigation for 5250 patents, ${ }^{54}$ at $\$ 100,000$ per patent, of $\$ 524$ million. The amount attributable to validity for 5250 patents, at $\$ 50,000$ per patent, is $\$ 262$ million.

The licensing numbers are much more of an estimate than the numbers for either prosecution or litigation. Because I don't have hard numbers, in the calculations that follow I will work with a range of possible numbers. In any event, the important lesson is that the overwhelming majority of patents are never used in a way that calls their validity into question.

\footnotetext{
52 This is obviously an important number for this article, and I am troubled that it is only an estimate. In Subpart IV.A, I relax this assumption to see how it affects the results.

For what it's worth, while several academics thought the $5 \%$ number was too low, some experienced patent prosecutors told me it was too high. One former patent prosecutor for a major technology company said that his company's rule of thumb was that only $1 \%$ of their patents were worth licensing. For other estimates roughly in line with my own, see Steven C. Carlson, Patent Pools and the Antitrust Dilemma, 16 YALE J. REG. 359, 385 (1999) ("Most infringed patents are not worth defending in court ... Even in the pharmaceutical industry, where patents are most valuable, eight out of ten patents typically produce no value for their holders."); Hearings on Global and InnovationBased Competition Before the Fed. Trade Comm'n 55 (1995) (statement of F.M. Scherer, Professor, Harvard Univ.).

53 Some empirical work in the international technology-licensing context, where the costs are likely to be higher, sets a value of about $\$ 100,000$ per transaction. See FaroK J. Contractor, INTERNATIONAL TECHNOLOGY LICENSING: COMPENSATION, COSTS, AND NEGOTIATION 105 (1981). This number is likely to be significantly higher than the cost per patent of domestic licensing, both because international deals tend to be more expensive and because many transactions involve more than one patent.

${ }^{54} 150,000$ patents per year times $3.5 \%$ ( $5 \%$ licensing rate, less the $1.5 \%$ that involve litigation).
} 


\section{HOW TO IMPROVE THE PATENT SYSTEM}

Suppose we agree with the host of commentators suggesting that there are too many bad patents in the system, and we want to take steps to weed out some of those patents. How should we go about doing it?

One way to do it - the method suggested by some advocates of patent reform ${ }^{55}$ - would be to have PTO examiners spend more time examining patents and, in particular, more time searching the prior art. More time means more money will be spent by both the PTO (to hire additional examiners) and by patent applicants (for additional legal fees to respond to the new rejections these additional examiners will doubtless issue). Doubling the amount of time examiners spend reviewing a patent from eighteen hours to thirty-six hours might seem a reasonable place to start. Doing so wouldn't double the cost of prosecution, because much of that cost is incurred drafting the initial application, and those costs would remain unchanged. But it might mean a fifty percent increase in the cost of prosecution, from an average of $\$ 20,000$ per original applications to $\$ 30,000$ (and from $\$ 5,000$ to $\$ 7,500$ for continuing prosecution applications). ${ }^{56}$ It should also mean that fewer patents issue, though the size of the drop is hard to estimate. The reduction will depend on the quality of the patents that currently issue and how many of the bad patents that currently issue can be smoked out merely by adding a few more hours to an examiner's evaluation. Let us assume the number of total issued patents would drop by ten percent to 135,000 per year as a result of truly final rejections of more applications by the PTO. ${ }^{57}$ Finally, a more comprehensive examination process might deter some people from filing

\footnotetext{
55 This argument is particularly common in the popular press. See, e.g., Gleick, supra note 1, at 44; Marc J. Lane, Talking Entrepreneurship: Patent Office's Monopoly Game Hurting Innovation, CraIN's CHI. Bus., June 5, 2000; Philip E. Ross, Patently Absurd: Technology and Gamesmanship Have Overwhelmed the U.S. Patent Office. How to Fix It?, ForBes, May 29, 2000. Members of Congress have also made suggestions along these lines. See Victoria Slind-Flor, Bar Reacts to Bezos Patent Reform Plan, NAT'L L.J., Mar. 27, 2000 (quoting Representative Coble: "If everyone would keep their grubby hands off the PTO's fees, the agency could hire and retain even more examiners to ensure that only quality patents are issued."). Patent examiners themselves have also taken this position. See Patent Reform and the Patent and Trademark Office Reauthorization for Fiscal Year 2000 Before the Subcomm. on Courts and Intellectual Prop. of the House Comm. on the Judiciary, 106th Cong. 88 (1999) (statement of Ronald J. Stern, President, Patent Office Prof'l Ass'n) ("Patent examination needs to be enhanced by providing more time for examination."). Indeed, Bruce Lehman, then Commissioner of the PTO, himself took that position back in 1994, explaining "[w]e are going to have to re-engineer the Patent and Trademark Office so that we give [examiners] more time and more resources. That has a price tag." George Leopold, Congress, PTO Ponder Ways to Streamline Operation, EleCtRICAl Eng. Times, Aug. 1, 1994.

56 Some of this increase will take the form of increased PTO fees needed to hire more examiners. PTO fees might be expected to roughly double to account for spending twice as much time per patent. Another component of the cost will be attorneys' fees needed to respond to the additional office actions examiners will generate, the necessity of drafting and explaining more claim amendments, and the additional work that will be generated for lawyers by a more thorough PTO prior art search that will presumably generate more prior art to evaluate and argue over.

${ }^{57}$ I actually suspect that this estimate, which would mean a proportionately greater drop of over $20 \%$ in the number of bad patents, is quite high. Quillen and Webster demonstrate that the PTO in its eighteen-hour review actually issues $97 \%$ of all the applications it receives. See Quillen \& Webster, supra note 11, at 9, tbl.6. To think that adding eighteen more hours will more than quadruple the effective rejection rate seems implausible. But I will use this number to be conservative.
} 
applications at all, both because of the increased costs and because of the decreased likelihood of actually getting a patent. To account for this, I have assumed that the number of applications would reverse its significant upward trend, and in fact would fall by about $10 \%$ to 247,500 under such a system. Thus, the total costs of prosecution under the new system would be 177,200 issued patents at $\$ 30,000$ per patent ( $\$ 5.32$ billion), plus 70,300 continuing prosecution applications ${ }^{58}$ at $\$ 7,500$ per patent (\$530 million), for a total cost of $\$ 5.85$ billion. This is an increase of $\$ 1.52$ billion in the cost of prosecution. ${ }^{59}$

How much money would this save on the back end? As we discussed in Part II, the total cost of patent litigation is $\$ 2.1$ billion, and the total cost of licensing outside of litigation is \$524 million. ${ }^{60}$ Thus, \$2.62 billion is spent each year on licensing and litigation. As noted above, it is reasonable to expect the enhanced examination system will prevent about ten percent of those patents from issuing. ${ }^{61}$ Thus, this cost should drop by ten percent, or $\$ 262$ million, much less than the $\$ 1.52$ billion we are spending to achieve this outcome.

An alternative proposal would require patent applicants to conduct a prior art search before filing their application and to disclose the results of that search to the PTO. This approach would have similar effects. Prior art searches cost somewhere between $\$ 5,000$ and $\$ 7,000$ each on average, though the actual price will differ depending on the complexity of the technology and how crowded the field is. A prior art search also requires the patentee to disclose more art, and therefore argue about that art with the examiner. Thus, it will increase legal fees as well. We can assume that requiring prior art searches would add between $\$ 8,000$ and $\$ 10,000$ to the cost of patent prosecution in most cases. ${ }^{62}$ If we assume

\footnotetext{
58275,000 applications less $10 \%=247,500$ applications. 125,000 would issue as patents, and the rest would go abandoned.

59 There will likely be indirect costs as well. A longer and more involved examination will likely lead to more initial rejections of all patent applications, even those that ultimately issue as patents. Thus, we might reasonably expect total prosecution times to increase under this strengthened examination system, even if many more examiners are hired to relieve the burden on those presently employed. Longer prosecution times in turn impose costs not only on the patentee, whose right of exclusivity is delayed, but also on others in the industry, who may be proceeding with their own development plans in ignorance of a pending patent application that covers their product.

${ }^{60}$ I have used the full costs here, not the percentage attributable to validity issues, because patent applications that do not issue under the more detailed examination regime can't be litigated or licensed at all, and so none of that cost is incurred.

${ }^{61}$ It is worth asking whether the patent applications that will not issue under this system would be more or less likely than average to be the patents that would have ended up in litigation. On the one hand, patentees are unlikely to spend money to litigate their weakest patents, so one might expect that the poor-quality patents that could have been knocked out by a slightly better examination process wouldn't be litigated at all, or at least wouldn't make it very far. On the other hand, it is possible that the patents that are invalidated under this stricter examination system are those with the broadest claims, and that those broad claims are more likely to be asserted in litigation. The text makes neither assumption, and instead simply assumes that a $10 \%$ reduction in the number of issued patents will translate into a $10 \%$ reduction in the number of litigated and licensed patents. Varying this assumption will of course vary the numbers.

62 This is true only if the patentee doesn't conduct a prior art search already. But most don't, and in particular experienced patent prosecutors are less likely to conduct a prior art search than novices. In part this is because the PTO requires that patent applicants disclose information of which they are aware, but does not require a search, so any search that is done may make it harder to get a patent. See FMC Corp. v. Hennessy Indus., 836 F.2d 521, 526 n.6 (Fed. Cir. 1987) ("As a general
} 
the same effects as above (that is, a reduction in the number of patents issued and the number applied for, as well as a reduction in the number of patents that survive to litigation), the cost-benefit structure is unchanged.

Another way to look at these numbers would be to say that society was willing to commit $\$ 1.28$ billion more than we currently do to weeding out bad patents. How should we spend that money? One way to spend it would be to add eighteen hours to the time examiners spend on each patent application (as noted above, the net cost of such a proposal is $\$ 1.52$ billion in increased prosecution costs minus $\$ 262$ million in litigation and licensing savings, or $\$ 1.26$ billion). Alternatively, we could more than double the amount of effort put into determining validity in court cases - that is, add over one thousand more hours of prior art searches, expert analyses, and judicial hearings on each patent that is actually litigated. If we want to get the validity decisions right in the cases that matter, the latter is surely a more efficient use of money than the former. ${ }^{63}$

The strong implication of these numbers is that society ought to resign itself to the fact that bad patents will issue, and attempt to deal with the problem ex post, when the patent is asserted in litigation. This result is admittedly counterintuitive. It depends crucially on the fact that very few patents are ever the subject of litigation, or even licensing. Because of this, money spent improving the PTO examination procedures will largely be wasted on examining the ninety-five percent of patents that will either never be used, or will be used in circumstances that don't crucially rely on the determination of validity. ${ }^{64}$

My argument becomes more intuitive if we take the position of PTO reformers a bit further. Suppose, for example, someone suggested that to minimize the risk of error we should conduct the equivalent of a full trial on validity (say, one thousand hours of examination) before granting a patent. This would certainly reduce the risk of bad patents getting through the system. But most people would rightly think such a suggestion ludicrous and unworkable. Why? Because they intuitively recognize that we simply cannot afford perfect decision making in each of the hundreds of thousands of cases on which the PTO has to make decisions. We understand rational ignorance on the part of the PTO, in other words - the only question is how much time we should spend per patent. From a cost perspective, the answer is not much.

rule, there is no duty to conduct a prior art search, and thus there is no duty to disclose art of which an applicant could have been aware."). In part, too, companies fear that if they find a competitor's patent during a prior art search, they are "on notice" of that patent for purposes of willful infringement if they are later sued.

${ }^{63}$ For this reason, it seems wrong to suggest that courts should defer to the PTO because of their greater expertise in the technical fields in question; $c f$. Arti K. Rai, Addressing the Patent Gold Rush: The Role of Deference to PTO Patent Denials, 2 WASH. U. J.L. \& POL'Y 199, 217 (2000) (suggesting such deference, albeit in the context of appeals from PTO rejections of patent applications). Whatever greater technical expertise does exist (and note that it is patent lawyers as well as judges who contribute information to the litigation system) is counterbalanced by the greater time devoted to validity in the litigation process.

64 Jay Thomas is one of the few to have recognized this point. He notes in passing that "although Patent Office shortcomings are apparent, it is equally obvious that an exhaustive prior art search for each application would be inefficient. Many patented inventions are never commercialized." Thomas, supra note 1, at 11. He does not pursue the implications of this idea, however. 


\section{OBJECTIONS}

Those who doubt this analysis might raise a number of objections. Some might question the assumptions that are necessarily built into some of these numbers. Others might question why I believe validity doesn't matter in circumstances where the patent isn't litigated or licensed. Still others might argue that the focus on legal costs ignores issues of deterrence, issues of delay and uncertainty, or issues of fairness and distribution. I consider each of these arguments in turn.

\section{A. Varying My Assumptions}

Perhaps you think I've played fast and loose with my statistics - that my assumptions are unrealistic, and that a more realistic assessment of the world would paint a very different picture. For that reason, this Subpart explores how some possible alternative numbers would affect my analysis.

I start by noting that many of the numbers in this study reflect pretty "hard" data. We know exactly how many patent applications are filed, and how many patents issue every year. We know how many cases are filed, and how many of them proceed to trial. We know how much patent litigation costs because we have survey data from the largest association of intellectual property lawyers in the country. Those numbers are what they are. Other numbers, such as the costs of patent prosecution, are estimates, but they seem to be reliable estimates. Not only do many different sources concur, but they also seem to fit with both my personal experience and the experience of those with whom I've talked.

Where the numbers are less solid, notably in the cost and frequency of licensing, I have tried to give PTO reformers the benefit of the doubt by estimating conservatively (in this case, by estimating on the high side both the amount of money spent on validity research in an average licensing transaction and the number of patents that are actually licensed for a royalty). Nonetheless, you may not believe me. So let's change some numbers. Suppose you think that fifteen percent of all patents are licensed for a royalty: that's 22,500 different new patents licensed each year. ${ }^{65}$ Further, let's say you think the average cost of the validity investigations done for a single patent in each of these 22,500 licensing transactions is even higher than $\$ 50,000$ - say $\$ 80,000$ out of a total cost per licensed patent of $\$ 130,000$. Both of these numbers strike me as too high, but never mind. Let's explore.

If fifteen percent of patents are licensed every year, that's 20,500 patents (once we subtract the 2,000 that go to litigation which we have already accounted for). These 20,500 licensed patents, at $\$ 80,000$ validity cost each, total $\$ 1.64$ billion per year spent investigating validity; 20,500 licensed patents at $\$ 130,000$ total licensing cost per patent, amounts to $\$ 2.66$ billion total spent on licensing per year. If we revise the calculations in Part III, adding $\$ 2.66$ billion to the $\$ 2.1$ billion spent on litigation, we have a total cost of $\$ 4.76$ billion. If we divide this by ten as we did in Part III, reflecting the reduced number of patents that

\footnotetext{
65 This represents far more than 22,500 new licensing agreements per year. A single revenue-
} producing patent may be (and often is) licensed to multiple entities over its lifetime. 
will be litigated and licensed, an enhanced examination program would save us $\$ 476$ million - still far less than the $\$ 1.52$ billion cost of adding just a few hours to the examination of each application. Even at this unrealistic cost estimate of $\$ 130,000$ per licensed patent, you would have to believe that more than 80,000 new patents are licensed for royalties every year-more than half of the patents issued each year, and more than pay their maintenance fees - to believe that doubling the examination time would save as much money as it would cost. There may be uncertainty about how much licensing occurs, but there isn't that much uncertainty.

The model is more sensitive to my assumptions about the number of patents that would be weeded out by adding eighteen hours more examination time to each patent. Again, it seems to me that my assumptions (that patent applications will actually go down as a result of this examination, despite their current trend, and that the new examination procedures will allow the PTO to weed out more than four times as many bad patents than they currently do without affecting any of the good ones) bend over backwards to be fair to PTO reformers. But let's relax those assumptions anyway. If you believe that eighteen hours of additional examination time would allow the PTO to weed out all the patents that turn out to be invalid in litigation (forty-six percent in recent years), ${ }^{66}$ and that it would weed out a similar number of bad patents in licensing, the total savings from the corresponding reduction in litigation and licensing would be forty-six percent of the $\$ 2.62$ billion currently spent on litigation and licensing, or $\$ 1.21$ billion. That is, even if the number of litigated and licensed patents were cut almost in half by this simple change in the PTO, it still wouldn't be cost-effective.

We could achieve a greater cost savings in litigation if we were to eliminate validity litigation altogether, for example by conclusively presuming that a patent once issued was valid. ${ }^{67}$ This would save another $\$ 625$ million spent on validity investigations and litigation in cases in which the patent really is objectively valid. With this new savings, the reform proposal might in fact turn out to be cost-effective. ${ }^{68}$

Think for a moment about what this would mean, however. To costjustify doubling the examination time for all patents, we would have to believe that the PTO would use the extra eighteen hours to make its examinations perfect - that is, that no bad patents would issue. And we would have to be so sure of this judgment that we would abolish an accused infringer's right to even try to persuade a court of the contrary, despite the fact that they have no right to participate in patent prosecution.

\footnotetext{
${ }^{66}$ See infra note 128.

${ }^{67}$ Cf. Kesan, supra note 1, at 26 (making a similar proposal contingent upon full disclosure of prior art by the patentee). Kesan's proposal is not for a conclusive presumption of validity, however, but merely for an extremely high presumption. This more moderate proposal will actually save less money than the proposal discussed in text.

${ }^{68}$ Even this is not a sure thing, however. The patent laws were amended in 1999 to add a thirdparty reexamination process that competitors can use. At the moment, virtually no one uses this system, because anyone who does so is foreclosed from making validity arguments in litigation. 35 U.S.C. $\S \S 311-318$ (West Supp. 2000). If validity litigation were abolished, competitors would rush to use this system as a second-best alternative. The costs of the system would have to be factored into the analysis in the text.
} 
Doing so would require substituting a very brief review (thirty-six hours) of a patent for the thousands of hours and considered judgment of trial and appellate courts. We should be willing to do this only if we truly believe that even brief consideration by a patent examiner is more likely to discern the truth than the trial process. I suspect that no one really believes this is possible. And if you do in fact believe thirty-six hours is enough for a perfect examination, it's worth asking why litigants spend thousands of hours on validity issues whenever a patent goes to court today, when they could presumably have an objectively correct answer for a much lower price. ${ }^{69}$

In short, the central insight of this Essay is not an artifact of the assumptions I've made. Even if we relax those assumptions beyond all reasonable bounds, the fundamental fact remains that litigation of a few patents is a far more efficient way of determining validity than giving a detailed ex ante examination to all patents.

\section{B. Does Validity Matter for Unasserted Patents?}

There is one assumption I have made that we have not yet considered. That is the assumption that the objective validity of a patent- the "right" answer, if you will, to the question of whether the patent should ever have issued-should matter only in cases in which the patent is asserted against an accused infringer, either in litigation or in licensing. This also might strike some people as counterintuitive. Wouldn't venture capitalists, competitors, and the company itself care whether the patent is a "good" one or a "bad" one, even if they don't themselves intend to pay money for it? In fact, though, I'm not sure that's true. To start with the easy case, significantly more than half of all issued patents are never used for any purpose whatsoever, except maybe to make their owners or inventors feel good about themselves. ${ }^{70}$ Surely it doesn't matter much whether these patents are "really" valid in any objective sense. These patents don't impose any direct cost on anyone, though there might be some indirect "clutter" cost associated with issuing so many patents. $^{71}$

Patents which are put to some use other than licensing - impressing investors, adding to asset counts, helping to define a market strategy, advertising one's "patented technology" or marking products, and so onalso don't seem to me to require objective validity. It is true that the existence of the patent itself is being used for some purpose-here, generally a communicative one. But the harm caused by letting even "bad"

\footnotetext{
69 Indeed, some evidence of how the patent bar views the PTO examination system is the fact that essentially no one has opted for the new inter partes reexamination system over court litigation. See supra note 68 . The inter partes system allows competitors to participate in reexamination and bring their prior art to the attention of patent examiners. If it were reasonable to believe that the PTO would do a better job of examining patents than the court system, one would expect that many competitors would use this system to reevaluate the validity of patents in lieu of litigation. So it is striking that competitors have not only voted with their feet for litigation over PTO examination, but have done so unanimously.

70 This percentage includes not only those patents for which maintenance fees are not paid, but also some patents for which fees are paid, but which are still never used.

${ }^{71}$ This cost is likely to be minimal, if indeed it exists at all. The only reason competitors search the patent database is if they are or are likely to be involved in litigation.
} 
patents be used for such a purpose seems to be minimal. Sophisticated parties like venture capitalists or a potential merger partner generally understand what patents are, and what it means to have one. They are capable of discounting for the risk that the patent would be held invalid if it were ever enforced. ${ }^{72}$ While those parties might benefit from knowing the patents in question were objectively valid, there is no proposed system that will provide such information. The question is whether there is a significant benefit to society from increasing the probability that those communicative patents are valid; that would be true only if those who rely on information about these patents couldn't assess the probabilities easily.

Cross-licensing of multiple patents without royalty payments presents the strongest intuitive case for caring about the validity of a patent. Why should a party want to take a license to a patent that isn't really valid anyway? One answer is the one just given: parties in crosslicensing transactions tend to be sophisticated entities with patents of their own, who understand and can discount for the possibility that the patent might be objectively invalid. Further, these licenses tend to involve multiple patents on each side, and (in the circumstances I have postulated) the parties essentially trade patent rights, rather than one party paying anything to the other. In these circumstances, it hardly seems likely that the objective invalidity of one patent in this group would kill the deal, though it conceivably could affect the decision to make the cross-license royalty-free in marginal cases.

\section{The Social Cost of Bad Patents}

Probably the most common objection to the claims made in Part III will be that they ignore the social cost of issuing bad patents. This is not entirely true. The social cost of bad patents comes in several forms. First, bad patents that are litigated impose litigation costs on society; those costs have already been considered. ${ }^{73}$ Second, bad patents that are licensed impose legal fees on licensees; those costs too have already been considered. Third, some licensees may pay a royalty rather than fight even a bad patent in court. Those royalty payments are a social cost to bad patents that I have not yet considered. Finally, it is possible that the mere existence of bad patents that aren't litigated or licensed may nonetheless deter some lawful competitive conduct. In this Subpart, I

\footnotetext{
72 Indeed, venture capitalists often evaluate companies on the basis of patent applications, where the determination necessarily involves uncertainty even as to whether the patent will issue at all.

Because venture capitalists can be expected to discount the value of patents, the "overinvestment” critique offered by Lunney and others doesn't apply here. See Glynn S. Lunney, Jr., Reexamining Copyright's Incentives-Access Paradigm, 49 VAND. L. REV. 483 (1996) (arguing that overly strong intellectual property rights promote overinvestment in intellectual property, inefficiently drawing assets away from other productive sectors of the economy).

73 I have not included patent damages granted at trial as a social cost of bad patents. We do not have a perfect measure of which patents are objectively valid and which objectively invalid, but it seems unreasonable to assume both that the courts will erroneously validate bad patents, and that some marginal improvements in the patent system would have weeded out those same patents. So if a patent is held valid and infringed in court, the damages that ensue are a cost to the patent system as a whole, but they aren't attributable to bad patents.
} 
consider these latter two forms of social cost to see if they change my analysis.

The social cost of issuing bad patents is different than the social cost of the patent system itself. The patent system intentionally restricts competition in certain technologies to encourage innovation. Doing so imposes a social cost, though the judgment of the patent system is that this cost is outweighed by the benefit to innovation. ${ }^{74}$ That social cost is not at issue here; rather, it is only the cost of issuing marginal bad patents that matters for my analysis.

1. In Terrorem Effects.-A more serious concern is that potential competitors or follow-on innovators in a field might be deterred from entering the field by the existence of patents owned by their competitors. On this view, when a patentee obtains a patent, the existence of the patent itself sends a powerful signal to competitors: "stay away." If patents do indeed have such an inherent "in terrorem" effect, then issuing bad patents has a real cost to society. The mere fact that those bad patents issued will deter some socially optimal behavior by competitors, imposing a cost on society that I have not yet taken into account.

There is something to this objection. Certainly the issuance of bad patents has the potential to deter competition that should be lawful in some marginal cases. But this concern can be overstated. First, by hypothesis we are talking only about the subset of patents that are never litigated or licensed. The vast majority of these patents simply exist; the in terrorem concern requires us to believe that competitors are regularly searching patent databases to make sure they are not infringing a patent that no one has brought to their attention. In my experience, this is simply not the way businesses operate. If they think about the problem at all, most sophisticated companies strenuously avoid reading other companies' patents because they don't want to be charged with knowledge of the patent's existence. ${ }^{75}$ But far more companies simply don't consider their potential patent liability unless or until a patent is brought to their attention.

So the patents with the most likely in terrorem effect must be ones that the patentee has tried and failed to license. In those cases, competitors or potential competitors may have received a letter alerting them to the existence of the patent, though that letter will likely have been

\footnotetext{
74 There is a great deal of literature attempting to assess whether that judgment is accurate or not, usually without success. George Priest complained years ago that there was virtually no useful economic evidence addressing the impact of intellectual property. George Priest, What Economists Can Tell Lawyers About Intellectual Property, 8 RES. L. \& ECON. 19 (1986). Fritz Machlup told Congress that economists had essentially no useful conclusions to draw on the nature of the patent system. See An Economic Review of the Patent System Before the S. Subcomm. on Patents, Trademarks, and Copyrights of the S. Comm. on the Judiciary, 85th Cong. 55 (1958) (statement of Fritz Machlup). For some of the disagreements among historians over the impact of the patent system on innovation, see Robert P. Merges et Al., InTEllectual Property in the New TeChNOLOGICAL AGE 126-27 (2d ed. 2000). That broader analysis is beyond the scope of this Essay; suffice it to say that if the patent system as a whole is a bad idea, as some claim, neither the proposed reforms I discuss nor my objections to them matter very much.

75 Continuing to infringe a patent once you become aware of it makes you liable for willful infringement, which can justify an award of treble damages against you. See, e.g., Comark Comm. Inc. v. Harris Corp., 156 F.3d 1182 (Fed. Cir. 1998).
} 
couched in extremely bland terms, purporting merely to make the competitor aware of the patent in case it should want to take a license. ${ }^{76}$ The recipient may ignore the letter, ${ }^{77}$ or it may react. The most common reaction is to obtain an opinion letter from counsel advising whether or not the patent is valid, and whether or not the recipient infringes. ${ }^{78}$ Based on the advice of counsel, the company might conceivably change its business plans, but the recipient's counsel will rarely advise such a course of action when the patent is objectively invalid. Another possible reaction is to give in without a fight. Some companies, especially small ones unsophisticated in patent law, may simply drop their plans to sell a product once a patent is brought to their attention, without even entering into a license negotiation. Again, though, this is an unusual reaction.

I don't mean by the preceding discussion to dismiss the in terrorem effect altogether. But I do think it is generally strongest in cases in which the patent is litigated or licensed at some point in its life, and in cases in which the patent is objectively valid. Once we exclude those cases, as we must do in measuring the merits of my thesis, the effect is likely to be a small one. Nonetheless, in part because it is hard to quantify any chill to innovation that might result, I have taken this concern into account in my suggestions for reform. ${ }^{79}$

2. Holdup Licensing.-Patent owners might try to game the system by seeking to license even clearly bad patents for royalty payments small enough that licensees decide it is not worth going to court. This sort of "nuisance value" claim occurs in all sorts of contexts, most notably in securities litigation. ${ }^{80}$ When it occurs in the patent system, as it doubtless does in some cases, the result is inefficiency in society's allocation of resources. Innocent competitors that are not infringing a valid patent nonetheless pay money to the owners of invalid patents; this transfer encourages patenting and discourages competition to a greater extent than is socially optimal.

It is hard to know how much money is transferred from licensees to

76 The letters are written in this roundabout way because if the patentee actually comes out and suggests that the recipient infringes the patent, the recipient has standing to file suit for declaratory judgment of noninfringement, an act which confers significant procedural advantages. See Amana Refrigeration, Inc. v. Quadlux, Inc., 172 F.3d 852 (Fed. Cir. 1999) (holding that under the Declaratory Judgment Act, a district court has jurisdiction if there is an actual controversy, and that an actual controversy exists if there is an explicit threat by the patentee which creates a reasonable apprehension on the part of the declaratory plaintiff that it will face an infringement suit, and present activity which could constitute infringement); Kimberly A. Moore, Forum Shopping in Patent Cases: Does Geographic Choice Affect Innovation? 79 N.C. L. REV. 889, 920 (2001). As a result, patent lawyers invariably advise their clients to write neutral letters that don't give the recipient a reasonable apprehension of being sued.

77 One general counsel told me that his company never does anything about such a letter unless it gets a follow-up letter or call from the patentee.

78 As a result, one could get a sense of the dimensions of this problem by collecting data on how often companies get opinions from patent counsel involving patents that never end up being litigated or licensed to anyone. I suspect this is a relatively infrequent occurrence, but I have no data to support or refute that hunch.

79 See infra notes $99-137$ and accompanying text.

80 Cf. Janet Cooper Alexander, Do the Merits Matter? A Study of Settlements in Securities Class Actions, 43 STAN. L. REV. 497 (1991) (examining securities cases that settled for nuisance value regardless of merit). 
patentees through such holdup claims, and (more important for my purposes) how much less money would be transferred under a more robust examination system. But with some plausible assumptions, we can generate some ballpark figures. To calculate an upper bound on the avoidable social costs from holdup licensing, I begin by recognizing that the possible number of holdup situations is limited by the total number of patents licensed for revenue or litigated but settled. There are 6,750 such patents per year - 5,250 licensed without litigation, and 1,500 litigated but not tried. Next, the avoidable holdup situations are a function of how many of those patents will be weeded out through eighteen hours additional examination. ${ }^{81}$ I earlier determined a high estimate for that number to be around ten percent of total patents. This means that, at most, 675 new patents per year are involved in avoidable holdups. This number is no doubt an exaggeration because it assumes that every instance of licensing without litigation is in fact a holdup attributable to a bad patent and not to a legitimate business deal. A more plausible (but still extremely high) number would be that half of those deals are legitimate, and the other half are holdups. If so, we are talking about 338 patents involved in holdups. Those patents may be asserted against multiple parties.

What is the cost to industry of such holdups? Presumably each licensee being held up would not be willing to pay more than the cost of litigating the patent. If the patentee demands more, the licensee ought to be willing to go to trial instead. ${ }^{82}$ The weighted cost of litigation is $\$ 656,000$. $^{83}$ The total cost depends on how many defendants will be held up in this way. Earlier, we assumed that the average number was two per patent, a blended estimate reflecting the number of potential licensees actually approached, potential cost savings if defendants pool their resources, and the increased likelihood that at least one case will result in litigation as the number of potential licensees increases. Thus, even under the assumptions made here the maximum likely social cost of licensing holdups is 338 patents times two licensees each times $\$ 656,000$, or $\$ 443$ million. ${ }^{84}$ This is certainly a cost to take into account, but it doesn't

81 The discussion in text likely overstates the extent to which the holdup problem can be avoided. If an applicant is serious about asserting its patent, it is unlikely to give up easily in prosecution. Since it is impossible under current PTO rules for an examiner to ever finally reject an application, adding examination time to such a patent may simply delay the process and increase its cost without changing the ultimate outcome.

${ }^{82}$ To be sure, this assumes the licensee can determine relatively easily that the patent is invalid. If that is not true, perhaps because of some information asymmetry, the licensee should pay the expected cost of litigation plus the expected payout (the likely damages times the probability of losing the case). But in this particular context, it seems reasonable to assume that the licensee will figure out pretty easily that it is dealing with a bad patent. After all, the only cases we are considering here are cases that patent examiners will determine to be invalid based merely on eighteen hours more examination. These are presumably not the close cases that might ordinarily create uncertainty about trial outcomes.

${ }^{83}$ This is based on the calculations supra notes 28-32 and accompanying text. In brief, one case in sixteen costs $\$ 1.503$ million to litigate, while under the assumptions made there the remaining fifteen cases cost $\$ 599,000$ on average to litigate.

${ }^{84}$ In economic terms, the social cost of such a holdup is not the price actually paid by the licensees, but the deadweight loss caused by the resulting increase in licensee costs. That deadweight loss is in turn a function of the percentage increase in cost resulting from the license payment and the shape and elasticity of the demand curve. Even if the license payment were equivalent to a monop- 
outweigh the increased social cost of strengthening the prosecution system.

3. Treating Patents in Isolation.-A final limitation on the social cost of in terrorem and holdup effects involves the practical context in which most patents are actually asserted or licensed. While some patents are licensed in a stand-alone transaction, most patents are licensed either as part of a group of related patents, or as part of a "hybrid" transaction that bundles patents with trade secrets and know-how. ${ }^{85}$ In these cases, it may be difficult to separate out a licensee's motivation for entering into a license agreement. Some of the social costs estimated in this section may be overstated, therefore, because a license transaction would have occurred whether or not a patent that was only one part of a larger deal was objectively invalid.

4. Facilitating Collusion.-Licensees might agree to pay royalties on patents they know are invalid as part of a scheme to cartelize an industry. Thus, one potential cost of bad patents could be a cost to competition in highly concentrated industries. This is a real risk, though it is an easy one to overstate. In most industries in which cartels are feasible, they will form around a variety of mechanisms. It seems a stretch to say that the grant of a bad patent will enable a successful cartel that otherwise would never have come into being.

Nonetheless, the law should be vigilant to prevent such abuses of patent rights. Antitrust law forbids the use of patent licenses as a tool to cover a cartel. ${ }^{86}$ The Court's decision in Lear, Inc. v. Adkins ${ }^{87}$ may also provide incentives for licensees to challenge the validity of patents used to facilitate a cartel. Lear has come under sustained attack of late by both courts and commentators, ${ }^{88}$ but the fear of collusive licensing may actually be a good reason to retain Lear and permit licensees to challenge a patent's validity at any time.

\section{The Costs of Delay and Uncertainty}

A more serious objection to my model is that it considers only the costs of prosecution and litigation, and does not consider the costs im-

\footnotetext{
oly price - a decidedly unlikely assumption for a nuisance-value payment - the deadweight loss would not exceed the total of the license payment under normal circumstances. It could never do so if the demand curve were linear. Even under a hyperbolic demand curve, the deadweight loss would exceed the license payment only if the amount produced under competition $\left(\mathrm{Q}_{\mathrm{C}}\right)$ was nearly three times the amount produced under monopoly $\left(\mathrm{Q}_{\mathrm{M}}\right)$. More precisely, $\mathrm{Q}_{\mathrm{C}}>2.71 \mathrm{Q}_{\mathrm{M}}$. [Proof omitted]. While such circumstances are theoretically possible, they are unlikely. As a result, I use the total amount of the license payment as an estimated upper bound of the social cost from holdups.

85 See Fish \& Richardson P.C., Trade Secrets/Know-How and Hybrid Licenses, available at http://www.fr.com/publis/f_paper10.html ("[T]he trend is towards license packages that include a mix of rights.").

8615 U.S.C. § 1. See generally Herbert HovenKamp et al., Intellectual Property and ANTITRUST LAW ch. 34(B) (forthcoming 2001).

87395 U.S. 653 (1969).

88 See, e.g., Studiengesellschaft Kohle v. Shell Oil Co., 112 F.3d 1561, 1567 (Fed. Cir. 1997) (noting the Federal Circuit's attempts to distinguish later cases from Lear, denying protection of the Lear doctrine); Rochelle Cooper Dreyfuss, Dethroning Lear: Licensee Estoppel and the Incentive to Innovate, 72 VA. L. REV. 677, 680 (1986) (arguing that a major flaw in the Court's analysis was "its failure to consider the economic function played by licensee estoppel").
} 
posed by a delayed resolution of the validity question. Having to go through litigation to determine validity not only costs a great deal of money, but it takes quite a bit of time. Indeed, the average time between the issuance of a patent that would later be litigated and a final decision on its validity in litigation was 8.6 years. For many patents, the validity decision was not made until thirteen or fourteen years after the patent issued. ${ }^{89}$ During this period, both the patentee and potential infringers (accused and unaccused) are uncertain about their legal rights. Surely we would be better off knowing sooner rather than later whether a patent is valid. ${ }^{90}$

This is a valid objection. All other things being equal, we would like to resolve the validity of patents as early as possible. But all other things are not equal. For one thing, unless we are willing to give up validity litigation altogether and rely only on the judgment of the PTO as to validity, issued patents will still be subject to validity challenges, and thus the validity of litigated patents will continue to be uncertain ex ante even under an enhanced examination system. The only increase in certainty that such a system would achieve would come in those cases in which an enhanced examination system would reject a patent application that is allowed under the current system. For this subset of patents, generously estimated at ten percent of the total in Part III, there would be no patent under the new system, hence no litigation at all and therefore no uncertainty. But we are talking at most about only a couple hundred patents a year in this situation. ${ }^{91}$

Further, delay and uncertainty are not only factors in litigation. They affect patent prosecution too. An enhanced examination system will necessarily increase the delay in issuing patents, and therefore the uncertainty associated with the ownership of legal rights in an invention. This delay will primarily affect patent applicants, who will have to wait longer to learn whether they will get a patent and, if so, must wait longer to assert it. ${ }^{92}$ This delay won't be as long in any individual case as the delay caused by litigation. But it will affect all 275,000 applications every year.

Increasing the examination scrutiny imposed on patents will also likely result in the rejection of some objectively valid patents. In the discussion in Part III, I assumed that more examination time would enable

\footnotetext{
${ }^{89}$ See Allison \& Lemley, supra note 4, at 236 tbl.12.

90 Thus, Craig Nard argues in favor of a post-grant opposition proceeding on the grounds that it will increase certainty ex ante. See Craig Allen Nard, Certainty, Fence Building and the Useful Arts, 74 InD. L.J. 759, 795 (1999). But see Ian Ayres \& Paul Klemperer, Limiting Patentees' Market Power Without Reducing Innovation Incentives: The Perverse Benefits of Uncertainty and NonInjunctive Remedies, 97 MicH. L. REV. 985 (1999) (arguing in favor of uncertainty as to the validity of a patent).

91 Weeding out bad patents should increase the probability that those patents that do make it through are valid. This in turn might affect decisions to litigate. But it would do so in unpredictable ways. For example, an increased probability of validity might induce more defendants to settle without litigation or at least before trial. On the other hand, the same increased probability might induce more patentees to litigate or license their patents. The net effect of these effects is unclear.

92 Prosecution uncertainty may also affect potential infringers, since under the 1999 changes to the U.S. patent system most patent applications will be published eighteen months after they are filed. See 35 U.S.C. $§ 122$ (b) (West Supp. 2000). Potential infringers who are aware of those published applications will have to wait longer to see whether a patent issues on the application.
} 
the PTO to weed out more bad patents without weeding out any good patents. But that is unrealistic. Systems that operate under uncertainty always balance type I and type II errors - false positives (here issuing bad patents) and false negatives (here failing to issue good patents). If we fail to issue good patents, we may reduce innovation incentives and interfere with the other socially valuable uses of patents, such as their financing function.

In short, delay and uncertainty impose costs on both sides of the equation. Balancing these effects is difficult, and I don't propose to do it here. Rather, I merely suggest that the costs of delay and uncertainty resulting from any given policy be taken into account in deciding what to do. I return to this issue in Part V.

\section{E. Distributional Effects}

There is one fundamental difference between the social costs of patent prosecution and the social costs of licensing and litigation. The former costs are internalized by patent applicants, who not only pay their own lawyers but also pay (through PTO fees) the costs of examination. ${ }^{93}$ By contrast, the costs of licensing and litigation are imposed not just on patent owners, but on accused infringers and, indirectly, on the public. ${ }^{94}$ Thus, relying more heavily on litigation rather than prosecution to determine patent validity has distributional as well as efficiency consequences.

This, too, is a fair concern. However, it is subject to some of the same caveats as the prior objection. First, enhanced examination will not eliminate validity disputes in litigation or licensing in the overwhelming majority of cases. These activities by their very nature impose costs on third parties; it is only in the relatively small set of cases that would never be brought (because the patents that are their subjects would never have issued) that any savings in cost will occur.

Second, it seems to me a contestable proposition that all the costs of determining validity should be borne by the patent applicant. It is true that the applicant is the one who would benefit from the issuance of the patent, so it might seem fair that the applicant should bear all the cost. But our society issues patents not because it desires private monopolies, but because granting patents in appropriate circumstances serves the public interest. It is equally plausible to argue that accused infringers-who have the most direct interest in the outcome of the validity proceeding and taxpayers should help shoulder the burden of determining who is right in this area, just as they do in any other sort of lawsuit.

Finally, this sort of cost-sharing serves instrumental goals as well. One problem with resting the validity decision entirely on examiners is

93 Indeed, they currently pay more than this, because of Congress's unconscionable decisions over the last several years to take money from the PTO user fees accounts and use them for the general federal revenue. See, e.g., Lisa Seachrist, House Committee Proposes Taking \$295M of Patent Fees, BioWorld TODAY, June 22, 2000 (discussing fee diversion).

94 I should make it clear that I have not considered as a "cost" of the patent system any royalty fees or damages paid by defendants as a result of infringing objectively valid patents. Not only are these costs a pure transfer from one party to another, they are a transfer explicitly intended by the patent statute. 
that, no matter how well qualified they are, they have no direct interest in the outcome. This is a good attribute in a decision-maker, but not such a good thing in a party advocate. Our system of litigation is founded on the idea that those with the most interest in an outcome will do the best research and make the best arguments for their position, and the truth will win out. On this view, the fact that accused infringers have to pay some of the cost of determining validity is not a bug in the system, but a feature. They will do a better job of proving a patent invalid than an examiner ever could.

Having said all this, I agree that one factor to consider in deciding how to allocate costs is that determining validity ex ante imposes fewer costs on third parties than waiting to determine validity ex post. I discuss some implications of this in Part V.

\section{F. The Credibility of the Patent System}

Finally, one might object that issuing bad patents brings the system into disrepute, which in turn may reduce the value of good patents, and therefore harm innovation. It is certainly true that people will think less highly of patents as a class if they know that many of those patents are objectively invalid. But I think this concern is overstated, for several reasons. First, for many of the patents I have discussed, especially the trophy patents and those that sit on the shelf, it is not clear that the level of quality of the patent system is all that important. Second, innovators adapt to the legal background they are given. There is no examination of trade secrets at all, essentially no examination of copyrights, and no required examination of trademarks. Yet in each case society builds assumptions (and indeed transactions) around the existence of these inchoate rights. It's even easier to "obtain" a bad trade secret or copyright claim than a bad patent, but that doesn't prevent trade secrets and copyrights from having value. As suggested above, venture capitalists and licensees already make the same calculation for patents. ${ }^{95}$ This brings me to my final point: it is implausible to think that any examination system could ever eliminate uncertainty over the validity of a patent. So those involved with the patent system will always have to make this calculation.

Two things about credibility do seem important. First, the legal rules should accurately reflect reality. If the PTO issues lots of bad patents, the legal system should take that fact into account in deciding the power of patents. I suggest below some ways to bring the law more in line with reality, notably by scaling back the presumption of validity. ${ }^{96}$ Second, patentees may want some signaling mechanism by which they can distinguish good patents from bad (or at least run-of-the-mill) ones. A Japanese-style elected examination system may allow such sorting. ${ }^{97}$

\section{IMPLICATIONS FOR OTHER REFORM PROPOSALS}

So far I have focused attention on suggestions that the PTO spend

\footnotetext{
95 See supra notes 70-72 and accompanying text.

96 See infra notes 119-132 and accompanying text.

${ }^{97}$ I discuss the Japanese system infra notes 117-118 and accompanying text.
} 
more time examining patents to weed out bad ones. But several other proposals for PTO reform have been floating around. In this Part, I consider the implications of my analysis for those proposals.

\section{A. Improving PTO Processes}

Nothing in my analysis suggests the PTO should not spend the money it is allocated as efficiently as possible. Some recent reforms within the organization have been aimed at enabling the PTO to operate more efficiently ${ }^{98}$ I see no problem with this. Similarly, Rob Merges makes a series of suggestions for improving the incentives for examiners. For example, Merges suggests changing the existing examiner incentive system so it rewards not only those who grant patents, but also those who reject applications in appropriate circumstances. ${ }^{99}$ He also suggests better training of examiners. ${ }^{100}$ These suggestions are perfectly consistent with my analysis, though one should be leery of changes that involve a significant increase in total PTO costs. ${ }^{101}$

Similarly, my analysis does not militate against increasing the budget of the patent office for reasons other than enhancing the examination each patent receives. For example, some people have suggested that the PTO needs to hire more examiners so that it may make decisions more quickly, holding the level of examination constant. ${ }^{102}$ This may or may not be true, but it is irrelevant for my analysis. Reducing the time patents spend in prosecution would presumably benefit patent holders in general, not just the subset who litigate their patents.

Finally, reform at the PTO might take the form not of changing its level of effort, but of changing the legal standard it is bound to apply. The current legal standard assumes an application is patentable; the burden is on the examiner to present a prima facie case of invalidity. ${ }^{103}$ There is a plausible legal argument for reversing this presumption and requiring patent applicants to shoulder the burden of proving their invention is patentable. Whether reform along these lines would increase the cost of the system is a complex question. While applying the new standard in the first instance would probably not be any more costly, the unique nature of the U.S. patent prosecution system, in which it is virtually impossible for an examiner to reject a patent application for good, ${ }^{104}$

98 The American Inventor Protection Act of 1999 established the PTO as a quasi-independent "government corporation" within the Department of Commerce, giving it more administrative autonomy. See generally 35 U.S.C. § 1(a) (West Supp. 2000) (laying down the history, authority, and responsibilities of the PTO).

99 Merges, supra note 1, at 606-09. The Quillen-Webster study dramatically demonstrates the need for such a reform. See Quillen \& Webster, supra note 11.

100 Merges, supra note 1, at 607.

101 Thus, Merges also suggests paying examiners salaries competitive with what engineers earn in the private sector, which might involve doubling the PTO's labor budget. See id. at 606-607 (noting representative figures for salaries).

102 I confess that I've argued this myself. See Lemley, supra note 22, at 147 . Congress was sufficiently concerned about the possibility of delay caused by the PTO that it amended the patent statute in 1999 to insulate patent applicants from loss occasioned by examiner delay. See 35 U.S.C. $\S$ 154(b).

103 See, e.g., In re Kotzab, 217 F.3d 1365, 1371 (Fed. Cir. 2000).

104 See, e.g., Quillen \& Webster, supra note 11 (discussing the process of abandonment and refiling). 
may mean that a more stringent examination standard will simply result in a more protracted prosecution process.

\section{B. Third-Party Oppositions}

A number of commentators have suggested that the United States should adopt a pre-grant opposition system like those in Europe and Japan, under which interested third parties could challenge applications before the PTO issues the patents. ${ }^{105}$ Historically, the U.S. has not allowed third parties to participate at all in examining patents, and has given them only a limited role in calling for an ex parte "reexamination" of a patent after it has issued. Recent changes to the law would permit third party participation in reexamination, but these changes still don't permit third parties to oppose an application before it issues. ${ }^{106}$ Further, the new third-party reexamination system is unlikely to be used much, because anyone who participates in this system must forego their right to challenge validity in court if they are ever sued for infringement on the patent. ${ }^{107}$

Whether an opposition system is consistent with my analysis is a difficult question. On the one hand, a pre-grant opposition proceeding would significantly increase the cost of prosecution in cases in which it is used. ${ }^{108}$ Thus, one might class it as merely a variant of the enhanced prosecution system. But there is a significant difference between enhanced prosecution and third-party opposition. Oppositions will only be filed in certain cases, and presumably a minority of cases. Merges reports that in Europe between 1994 and 1997, only about $6.5 \%$ of issued patents were opposed. ${ }^{109}$ If the patent applications that are opposed are also the ones most likely to be licensed or litigated, the opposition proceeding begins to look more like an earlier and cheaper type of litigation proceeding. F.M. Scherer has offered some evidence that this is in fact the case. 110

105 See, e.g., Dreyfuss, supra note 88; Mark D. Janis, Rethinking Reexamination: Toward a Viable Administrative Revocation System for U.S. Patent Law, 11 HARV. J.L. \& TECH. 1 (1997); Merges, supra note 1, at 610-15; Nard, supra note 90, at 795; J.H. Reichman, From Free Riders to Fair Followers: Global Competition Under the TRIPS Agreement, 29 N.Y.U. J. INT'L L. \& POL. 11, 31 (1997). Jay Thomas has proposed an interesting variant on pre-grant opposition, in which parties who submit patent-defeating prior art are paid a bonus or finder's fee. See Thomas, supra note 1.

106 See 35 U.S.C. § 122(c) (precluding pre-grant opposition to published patent applications).

10735 U.S.C. $\$ 315(\mathrm{c})$. Thus, commentators (and everyone in the patent bar I've talked to on the subject) think the third-party examination system as currently written is essentially worthless. See, e.g., Janis, supra note 17, at 481; see also Thomas, supra note 1, at 26 (describing reexamination as "one of the greatest failures of the modern patent system"). For an explanation that identifies some limited circumstances in which the system might be used, see M. Patricia Thayer et al., Inter Partes Reexamination: The United States Joins Europe and Japan in Providing an Adversarial Administrative Procedure for Testing Patent Validity (2001) (working paper, on file with author).

108 An opposition system would also introduce some of the elements of the litigation system into prosecution: delay, uncertainty, and the imposition of costs on third parties (though in this case only third parties that had voluntarily taken on the obligation). The amount of cost and delay would of course depend on the nature of the system. But one probable parallel is interference proceedings, a feature of existing patent law under which two applicants for a patent on the same invention dispute priority. Despite the fact that only priority of invention is at stake, this inter partes proceeding is notoriously protracted - some cases have taken close to 30 years to resolve. See, e.g., Standard Oil Co. (Indiana) v. Montedison S.p.A., 664 F.2d 356 (3d Cir. 1981) (resolving an interference proceeding based on 1953 patent applications).

109 Merges, supra note 1, at 613 tbl.2. 
the case. ${ }^{110}$

Thus, an opposition system might be consistent with the insight of this article, if one believes that applications that are opposed tend to be the ones that are later litigated (or at least licensed). But if this is not true-if there is a substantial disconnect between applications that would be opposed and patents that are ultimately litigated - an opposition system could be a waste of time and money on everyone's part. ${ }^{11}$

\section{A Registration System}

Some commentators have taken the opposite tack to the one criticized here, suggesting that the examination system should be thrown out altogether and replaced with some sort of a registration or "petty-patent" system. Most of these suggestions are variants on a registration system, rather than a pure registration system, because the registration process would coexist with the existing patent structure. ${ }^{12}$ But the basic argument is an extreme form of the one I have made here: that not only shouldn't we increase the time spent in prosecution, we should reduce or eliminate examination entirely, and rely on the litigation process to sort the good patents from the bad.

This argument is not as radical as it sounds. Patents are the only part of intellectual property law that actually requires government examination and approval as a prerequisite to filing a lawsuit. In copyright and trade secret law, the government doesn't need to "issue" a copyright or trade secret for the owner to go to court. ${ }^{113}$ While there is an examination system in trademark law, trademark owners can file suit even if they don't register their marks. ${ }^{114}$

110 See Dietmar Harhoff et al., Citations, Family Size, Opposition and the Value of Patent Rights (1999) (working paper, on file with author) (providing a study of German oppositions as a predictor of patent value, finding that an opposition proceeding is the single best predictor of the ultimate value of a patent).

111 The metric used to analyze Thomas's proposal for "bounties" paid to those who submit invalidating prior art should be similar. If there is reason to believe that the bounties would encourage prior art submissions primarily about patents that are likely candidates for future litigation, it may serve a useful purpose. However, if the bounties encourage prior art submitters to pick "lowhanging fruit" by submitting art to invalidate obviously worthless patents, they may increase the cost of the system with little corresponding benefit. Unless great care is taken in designing the system, I fear the latter is the more likely result.

112 Thus, Ann Bartow calls for an "origination patent" system to provide a lesser form of protection to those who mostly want patent protection as a marketing device. See Bartow, supra note 47, at 16-25. Richard Stern promotes a "petty-patent" system as a hybrid between patent and copyright protection that might be appropriate for software. See Richard H. Stern, On Defining the Concept of Infringement of Intellectual Property Rights in Algorithms and Other Abstract Computer-Related Ideas, 23 AIPLA Q.J. 401 (1995). But see Mark D. Janis, Second-Tier Patent Protection, 40 HARV. INT'L L.J. 151 (1999) (being more critical of such "second-tier" patent systems).

113 There is a copyright registration system, and applying for registration is a prerequisite for a United States copyright owner to file a lawsuit. Tellingly, however, even in those rare cases in which copyright registration is refused, the refusal itself is sufficient for the copyright owner to go ahead with the infringement lawsuit. 17 U.S.C. § 411 (a) (West Supp. 2000).

114 See 15 U.S.C. $\$ 1125$ (a). There are advantages to trademark registration, of course. Registration gives constructive nationwide use and priority, 15 U.S.C. $\S \S 1057(\mathrm{c}), 1072$; it permits a mark to achieve "incontestable" status, 15 U.S.C. $§ 1065$; it gives the mark owner the right to invoke the assistance of customs officials in barring importation, 15 U.S.C. $\S 1124$; and it gives the mark owner enhanced remedies, 15 U.S.C. $\S \S 1116-1120$. 
My analysis may give some comfort to proponents of a registration system. After all, if it would cost much more to expand prosecution than to litigate the issue of validity after the fact, maybe the contrapositive is also true: it may be more cost-effective to reduce the time and money spent on examination below its current level, even at the cost of increasing the number of lawsuits and licensing deals.

Nonetheless, I do not endorse a pure registration system, for several reasons. First, a true registration system would mean more than merely reducing the number of hours devoted to examination-it would mean eliminating examination altogether. Even if a reduction in prosecution expenditures would be cost-effective, it does not follow that eliminating them would be. At the very least, we would want more concrete estimates than we currently have of how many people would register and enforce patents under such a system and how many of the additional applications would be spurious. Second, while I am not fully persuaded by the arguments noted in the previous sections regarding in terrorem deterrence, holdup, delay, uncertainty and cost shifting, ${ }^{115} \mathrm{I}$ do think they have some force. Beyond a certain point, it may be unwise to shift the burden of determining validity so far away from the patent applicant and towards its competitors. Finally, examination may serve a socially useful function by requiring patentees to restrict the scope of their claims, and therefore help prevent some abusive claims that cover entire industries. ${ }^{116}$

A possible compromise solution is a hybrid registration-examination system along the lines of the Japanese system. ${ }^{117}$ Under a hybrid system, a patentee would register its invention, but the invention would not be examined unless the patentee elected examination. A patentee could not enforce the patent against a third party unless it first had the patent examined. ${ }^{118}$ The virtue of this system is that it forces the patentee to disclose its private information about the quality and likely use of its patent by deciding whether and when to have the patent examined. Because only a subset of patents would be examined, and that subset are presumably considered valuable by patentees and are likely candidates for litigation, the examiners in a hybrid system could afford to devote substantially more resources to those patents. Such a system therefore has the virtue of more cost-effectively improving the examination process than the proposals I criticize.

\footnotetext{
115 See supra notes 73-80 and accompanying text.

116 This is particularly true in light of the Federal Circuit's en banc decision in Festo Corp. v. Shoketsu Kinzoki Kogyo Kabushiki Co., 234 F.3d 558 (Fed. Cir. 2000) (en banc), cert. granted, 69 U.S.L.W. 3673 (2001), precluding resort to the doctrine of equivalents once the patentee has amended a claim element during prosecution.

117 See T. TANABE \& HAROLD Wegner, JAPANESE PATENT LAW (1979) (describing the Japanese patent system).

118 This feature is particularly important, and distinguishes the proposed hybrid system from the sort of "petty-patent" systems that exist in many countries. See Janis, supra note 112 (describing such systems). A variant of this system is the old English caveat system, under which patents would issue without examination unless a competitor had filed a "caveat" - a request to be informed of any applications filed covering certain subject matter. On the caveat system, which was used in the U.S. during the $19^{\text {th }}$ Century as well, see Malla Pollack, The Possible Unconstitutionality of Business Method Patents: Common Sense and History 20 (2001) (working paper, on file with author).
} 


\section{Litigation Reforms}

My analysis does have significant implications for the treatment of patent validity in litigation. Patent litigation proceeds on the assumption that issued patents have been subjected to a thorough examination process, and that the PTO is unlikely to have made a mistake. This assumption is both explicit and implicit. The patent statute imposes a presumption that issued patents are valid. ${ }^{119}$ The courts have read this statute to impose a burden on the accused infringer to demonstrate invalidity of a patent by clear and convincing evidence. ${ }^{120}$ The Federal Circuit has recently strengthened that burden by backing away from an earlier rule that applied this presumption only to arguments and prior art actually considered during prosecution. ${ }^{121}$ The court now says the presumption exists even with respect to art that the examiner did not consider at all. ${ }^{122}$ The examiners are presumed to know their fields, and to know the scope of the claims they allow. ${ }^{123}$ These explicit legal rules are strengthened by jury psychology. Jurors are notoriously reluctant to second-guess patent examiners, not only because they assume examiners know more than they do but because they believe examiners spend much more time examining any given patent than they actually do. ${ }^{124}$

The presumption of validity has little if any basis in fact. Examiners do not in fact spend long hours poring over a patent application or the prior art. They spend very little time, and far less than either the lawyers or the triers of fact in infringement cases. They regularly miss the most relevant prior art. The Quillen-Webster study suggests, moreover, that they ultimately issue an astonishing ninety-seven percent of the unique applications filed. ${ }^{125}$ The law should not ignore the fact that a patent application has been examined, but it seems clear we give that examination process far too much weight. At a bare minimum, the presumption of validity should be pared back so that it covers only prior art references and arguments actually considered by the examiner. There is simply no reason to defer to the examiner's purported decision on an issue the examiner did not even address. But I would go further and eliminate the

\footnotetext{
11935 U.S.C. $\S 282$ (West Supp. 2000).

120 See, e.g., Al-Site Corp. v. VSI Int'l., 174 F.3d 1308 (Fed. Cir. 1999) (describing the presumption of validity as "strong")

121 See, e.g., Mfg. Research Corp. v. Graybar Elec. Co., 679 F.2d 1355 (11th Cir. 1982); NDM Corp. v. Hayes Prod. Inc., 641 F.2d 1274 (9th Cir. 1981); Lee Blacksmith Inc. v. Lindsay Bros., 605 F.2d 341 (7th Cir. 1979) (adopting the "considered art only" rule).

122 See, e.g., Kahn v. General Motors Corp., 135 F.3d 1472, 1480 (Fed. Cir. 1998) (“The presentation of evidence that was not before the examiner does not change the presumption of validity"); Applied Materials, Inc. v. Advanced Semiconductor Materials Am. Inc., 98 F.3d 1563 (Fed. Cir. 1996) (holding the same).

${ }^{123}$ See, e.g., Al-Site, 174 F.3d at 1308 (stating that the presumption of validity carries with it " "a presumption that the examiner did his duty and knew what claims he was allowing" (quoting Intervet Am., Inc. v. Kee-Vet Labs., Inc., 887 F.2d 1050, 1054 (Fed. Cir. 1989))); W. Elec. v. Piezo Tech., 860 F.2d 428 (Fed. Cir. 1988) (holding that a presumption stands regardless of the expertise of the particular examiner in the field in question).

124 This argument is based on anecdotal evidence, but in fact there is statistical support for the propositions that juries tend to favor patentees on validity questions and that juries are unlikely to second-guess an examiner who has already considered and rejected a prior art reference. See Allison \& Lemley, supra note 4, at 212-13, 231-34.

125 Quillen \& Webster, supra note 11, at 9 tbl.6.
} 
clear and convincing evidence requirement altogether, ${ }^{126}$ making the presumption that a patent is valid rebuttable by a preponderance of the evidence. ${ }^{127}$ My argument in this article is based on the idea that it is more efficient to decide validity after in-depth consideration in those few cases in which it matters than to decide it upon a cursory review of all patent applications. My argument is undermined if validity litigation does not in fact involve a searching investigation of validity, but instead defers to the cursory review already conducted. Based on what we know of patent examinations, deference is not appropriate. ${ }^{128}$ If there is to be deference to PTO decisions in litigation, it should be coupled with some form of real third-party opposition system, and only patents that have been through that system should be entitled to deference.

If the general statutory presumption of validity is inappropriate, the conclusive presumption of validity temporarily afforded a pharmaceutical patent under the Hatch-Waxman Act is indefensible. As that statute has been implemented, a prospective generic manufacturer who wants to make a drug that may be covered by a patent files an abbreviated new drug application ("ANDA"), at which point the patentee is notified. If the patentee files an infringement lawsuit against the generic manufac-

126 Needless to say, therefore, I disagree with commentators such as Jay Kesan, who would strengthen the presumption of validity. See Kesan, supra note 1, at 26. Kesan's argument is that we don't need validity litigation if we give patent applicants sufficient incentive to disclose the relevant prior art in the first place. However, while such an approach might well encourage applicants to disclose prior art, the PTO could not evaluate all that prior art in a definitive way without spending much more time in prosecution than they currently do. Thus, Kesan's proposed system would likely result in patentees effectively insulating bad patents from judicial review by overwhelming patent examiners with prior art, knowing that the examiners won't be able to do a thorough analysis in the time they have available.

127 This proposal is in keeping with the standard used in trademark cases. Keeping the burden with the accused infringer takes some account of the fact that the patentee did go through some prosecution process. It also prevents procedural anomalies from arising in cases in which an accused infringer files for declaratory judgment that a patent is invalid.

128 A few scholars have defended deference to the PTO, but mostly in the context of appeals from the rejection of a patent application. See, e.g., Craig Allen Nard, Deference, Defiance, and the Useful Arts, 56 OHIO ST. L.J. 1415 (1995); Rai, supra note 63, at 202 (arguing that deference is appropriate to patent denials but not to patent grants, because the system is set up to err on the side of granting patents). These arguments tend to focus on the proper interpretation of the Administrative Procedures Act (APA). See generally Dickinson v. Zurko, 527 U.S. 150 (1999) (holding that the APA requires deference to PTO factfinding).

There is some evidence that deference by courts in practice is far less than complete. About $46 \%$ of all patents litigated to a final judgment on validity issues are held invalid. See Allison \& Lemley, supra note 4, at 205-07. This number includes decisions on appeal and at summary judgment. At trial, only $33 \%$ of patents are held invalid. See Moore, supra note 25, at 390 Table 4 . Thus, courts are clearly making some inquiry into validity on their own. I should note, however, that the invalidity numbers have declined significantly over the past 25 years, from $65 \%$ to $46 \%$. GLORIA K. Koenig, Patent InValidity: A Statistical and Substantive Analysis 4-19 to 4-23 (rev. ed. 1980); Allison \& Lemley, supra note 4, at 206 n.53. Thus, deference to the PTO by the courts seems to be on the rise.

Finally, it is worth noting some empirical evidence that suggests that the Federal Circuit's moves to strengthen the presumption of validity had the effect of increasing both the number of patent cases filed and the percentage that go to trial. See Jean O. Lanjouw \& Josh Lerner, The Enforcement of Intellectual Property Rights: A Survey of the Empirical Literature, 49/50 ANNALES D'ECONOMIE ET DE STATISTIQUE 223 (1998). Thus, the presumption of validity may actually account for some portion of the social cost of litigation over bad patents. 
turer, ${ }^{129}$ the FDA cannot proceed to consider the ANDA for thirty months, unless the Federal Circuit issues an opinion during that time holding the patent invalid. ${ }^{130}$ In effect, the FDA acts as if the patent is conclusively presumed valid unless the Federal Circuit instructs it otherwise. Even a district court determination of invalidity won't enable the generic to proceed with its application as long as there is an appeal pending. ${ }^{131}$ This presumption of validity has even less basis in fact than the litigation presumption, and its effect is to delay drug price competition for several years even where a patent is clearly invalid. This conclusive presumption of validity imposes significant social costs based on the assertion of bad patents in litigation, and should be abolished.

A second possible implication for litigation concerns the imposition of costs on an accused infringer who must defend against a "bad" patent. Leaving the validity determination until trial imposes significant costs on accused infringers. Where the validity issue wasn't close, and the patent was clearly invalid, it may make sense to shift some of those costs to the patentee. Unfortunately, the patent law makes it very difficult for a prevailing defendant to obtain an award of attorney's fees. The statute requires the case to be "exceptional."132 As a practical matter, patentees are far more likely to be awarded attorney's fees than accused infringers, because they can often get fees by proving "willful" infringement. ${ }^{133}$ By contrast, accused infringers normally won't get attorneys' fees unless they can prove that the suit was filed in bad faith. ${ }^{134}$ It may make sense to add some balance to the fee awards. In copyright law, for example, the standards for prevailing parties seeking a fee award are identical whether the party is a plaintiff or a defendant. The Supreme Court has identified the important public policy interests not only in enforcing copyrights but also in defending against unfounded copyright claims. ${ }^{135}$ The result of doing so has been a dramatic growth in fee awards to defendants in copyright cases. ${ }^{136}$ A similar rule might encourage more fee shifting in patent cases, and therefore help shift some of the burden of determining validity away from accused infringers.

Both of these suggestions would require changes in existing law. Those changes need not be complex, however, and do not necessarily require legislative intervention. The statutory presumption of validity does not specify that the presumption of validity can only be overcome by

\footnotetext{
129 The lawsuit would presumably proceed under 35 U.S.C. $\$ 271(\mathrm{e})$, as the generic has not yet begun making, using or selling the product and therefore does not violate $\S 271(\mathrm{a})$.

13021 C.F.R. $\S 314.107(b)(3)$.

$131 \mathrm{Id}$.

13235 U.S.C. $\S 285$.

133 See Great N. Corp. v. Davis Core \& Pad Co., Inc., 782 F.2d 159 (Fed. Cir. 1986) (holding that willful infringement alone can make a case "exceptional" and therefore justify a fee award).

134 See, e.g., Cambridge Prods., Ltd. v. Penn Nutrients, Inc., 962 F.2d 1048, 1050-51 (Fed. Cir. 1992) ("In the case of awards to prevailing accused infringers . . , exceptional cases are normally those of bad faith litigation or those involving fraud or inequitable conduct by the patentee in procuring the patent.").

135 See Fogerty v. Fantasy, Inc., 510 U.S. 517, 527 (1994).

136 See Jeffrey Edward Barnes, Comment, Attorney's Fee Awards in Federal Copyright Litigation After Fogerty v. Fantasy: Defendants are Winning Fees More Often, but the New Standard Still Favors Prevailing Plaintiffs, 47 UCLA L. REV. 1381 (2000).
} 
clear and convincing evidence. The clear and convincing evidence standard is a judicial creation, and courts could read the statute to impose a lesser burden on accused infringers. For example, $\S 282$ might be interpreted only to shift the burden of proof by preponderance of the evidence, and not to impose a higher evidentiary burden on accused infringers.

Section 285 provides that "[ $\mathrm{t}]$ he court in exceptional cases may award reasonable attorney fees to the prevailing party."137 Standing alone, there is nothing in this statutory provision that suggests its application should favor one side or the other. Thus, a court could quite plausibly read it as establishing a neutral standard for fee shifting. Because of the difficulty of proving a case "exceptional" in practice, however, Congress might choose to amend the statute to provide for fee shifting in cases in which a prevailing party on either side "has vindicated an important public interest."

\section{E. Directions for Research}

Finally, the analysis I have conducted suggests some directions for future research. While many of the numbers I employ are quite definite, or at least clear within ranges, some are not. We know very little about how many patents are licensed for royalties. We also don't know how intensively they are licensed-that is, how many licensees there are for each licensed patent. As we have seen, both of these numbers are critical to understanding the social costs of the patent system. Both seem fruitful areas for future empirical research.

\section{CONCLUSION}

The PTO is rationally ignorant of the objective validity of the patents it examines. For the PTO to gather all the information it needs to make real validity decisions would take an enormous investment of time and resources. Those decisions can be made much more efficiently in litigation, because only a tiny percentage of patents are ever litigated or even licensed to others. Thus, we should resign ourselves to living with a system in which "bad" patents do slip through the PTO undetected. Recognizing that this is the case, however, should also prompt us to strengthen the validity inquiry made by the trial courts. Courts should not be ignorant of the facts, and they should not presume that a patent is valid merely because the PTO says it is.

13735 U.S.C. $\$ 285$. 